Research Square
Preprints are preliminary reports that have not undergone peer review.

They should not be considered conclusive, used to inform clinical practice, or referenced by the media as validated information.

\title{
Optimization of energy consumption and analysis of the emission of greenhouse gases in the production of rice (Case study: Mazandaran province of Iran)
}

Adel Vahedi ( $\nabla$ vahedi_adel@yahoo.com )

Agricultural engineering group, guilan agricultural and natural resources research and education center, rasht, iran

Zahra Yousefi

Agricultural Research Group, Guilan Agricultural and Natural Resources Research and Education Center, (AREEO), Rasht, Iran

Ahmad Sharifi Malvajerdi

Agricultural Education Organization and Extension Directorate: Agricultural Research Education and Extension Organization

\section{Research}

Keywords: Efficiency, energy saving, input, output, return to scale, target energy

Posted Date: October 22nd, 2020

DOI: https://doi.org/10.21203/rs.3.rs-41411/v2

License: @ (i) This work is licensed under a Creative Commons Attribution 4.0 International License. Read Full License 


\section{Abstract}

The present study has been conducted to investigate the energy consumption pattern, the economic analysis of production and assessing the greenhouse gas emissions (GHG) resulting from the production of rice in the Mazandaran province. The input and output energies were calculated and energy indices were determined. The efficiency of the rice farms and the optimization of energy consumption were estimated by using data envelopment analysis (DEA) method and the amount of greenhouse gas emissions was determined after improving the consumption of inputs. Results showed, the total energies of consumed inputs and outputs for the production of paddy were calculated to be 91061.5 and $100967.95 \mathrm{MJ} \mathrm{ha}^{-1}$, respectively. The energy input of diesel fuel, machinery and chemical fertilizers were determined to be $41.27 \%, 19.63 \%$ and $19.58 \%$ of the total energy inputs, representing the most highly consumed energy inputs in the production of paddy.

\section{Introduction}

The efficient use of energy in agriculture leads to sustainable development of agriculture. The sustainable crop cultivation necessitates considering input and output energy flows, in the given production system [21].

The modern agriculture, as a result of excessive dependence on numerous inputs, is one of the most intensive energy consuming sectors [46]. Nowadays the inputs such as fuel, electricity, machinery, seed, fertilizers and chemicals have significant share on the energy supplies in the production system of modern agriculture [20]. The diversity of inputs has triggered remarkable changes in the energy consumption pattern of the agricultural sector and resulted in greater dependence on fossil fuel energy resources [34]. This can leave negative impacts on the environment and public health, resulting in excessive use of natural resources. Therefore, this point underlines the importance and necessity of investigating the energy consumption pattern in order to effectively employ it in the agriculture sector [42].

The limitation of farmlands, population growth, variation in infrastructure and tendency to high living standards are factors that have increased the consumption of energy in the agricultural sector. The effective use of energy in agriculture is one of the most important needs of sustainable development in agriculture [32].

Energy flow in agriculture can be categorized as direct and indirect, renewable and non-renewable. Energy and environmental audit are the most prevalent methods for investigating the efficiency of energy and environmental impacts of any production system [20]. The analysis of energy would illustrate how much energy could be used efficiently. Therefore, agriculture interacts with energy and they have a complementary structure [31].

The world population is projected to reach approximately 9 billion in 2050 [14]. It is estimated that the nutritional requirements of this population would be possible to be met through increasing the area under cultivation and increasing yield of production, necessitating further consumption of resources including fossil fuels, machinery, fertilizers, chemicals and other resources and from two perspectives, the use of primary resources aimed at ensuring the growth and survival of human being and the production of waste materials including various solid, liquid and gas pollutants have resulted in negative impacts on the environment. Raising awareness of the importance of the environment and the relevant impacts of the produced crops and consuming them motivates the provision of newer and more precise methods to alleviate these impacts. One of these methods that are expanding and being developed is the life cycle assessment method.

Analyzing the environmental impacts, determining the energy and economic indices are important imperatives in evaluating the systems of crop production.

In 2017 , the worldwide rice production equaled 769.657 million tons, out of which more than $90.5 \%$ was produced in Asia. The area under cultivation of rice is 167.249 million hectares and the average yield totals $4,602 \mathrm{~kg} \mathrm{ha}^{-1}[14]$.

The area under cultivation of crops in Iran is 11.7 million hectares of which $42.6 \%$ represents irrigated farms and $57.4 \%$ represents dryland farming. The area under cultivation of cereals in Iran totals 8.44 million hectares (71.7\%). The area under cultivation of wheat, barley, paddy and corn respectively comprise $70.22 \%, 20.84 \%, 7.06 \%$ and $1.88 \%$ of the total area under cultivation of cereals in the country.

The quantity of crop productions in Iran equals 83 million tons, of which $68.2 \%$ belongs to irrigated agriculture and $31.8 \%$ belongs to dryland farming. Out of the total produced crop in the country, 22.41 million tons (27\%) are cereals, where the shares of wheat, barley, paddy and corn are $65.12 \%, 16.62 \%, 13.04 \%$ and $5.22 \%$, respectively.

The area under cultivation of rice in Iran amounts to 596,035 ha, which is equivalent to $7.06 \%$ of area under cultivation of cereals in the country. Total quantity of the paddy produce in Iran adds up to 2,921,046 tons with an average yield of 4.9 tons per hectare.

Mazandaran province is one of the most important rice production areas in Iran where 218,293 ha of land is annually dedicated to paddy cultivation with a production quantity of $1,187,481$ tons and an average yield of 5.44 tons per hectare, while the area under cultivation of rice in the Guilan province equals to 197078 hectares with a production quantity of 912000 tons and an average yield of 4.62 tons per hectare [48].

However, there are some important environmental problems associated with rice production in Mazandaran province, for example, rice production with greenhouse gas emissions and methane has a negative impact on humans. In addition, the release of nitrite into water sources is another important problem. Initial studies have shown that energy consumption in rice fields is high while some of it is not used effectively.

The improvement of energy efficiency and the reduction of greenhouse gas emissions resulting from rice production in the Astaneh Ashrafiyeh city in the Guilan province were studied. The average technical efficiency, pure technical efficiency and scale efficiency of the paddy fields were determined to be 0.79 , 0.98 and 0.81 . Out of 120 paddy fields investigated, 35 farms were efficient in the constant return to scale model and 72 farms were efficient in the variable

Page 2/27 
return to scale model. With the improvement of the consumed inputs, the total energy saving was determined to be $19.8 \%$, while the consumptive fuel energy had the biggest share among the energy inputs out of the total energy saving at $43.41 \%$. The quantities of greenhouse gas emissions under the real and improved states were reported to be $1,847.26 \mathrm{~kg} \mathrm{CO}_{2}$ eq. ha- ${ }^{-1}$ and $1,483.52 \mathrm{~kg} \mathrm{CO}_{2}$ eq. ha ${ }^{-1}$, respectively [36].

In investigating the consumptive energy of rice production in the Guilan province, energy use efficiency and energy productivity were expressed to be 1.53 and $0.09 \mathrm{~kg} \mathrm{MJ}^{-1}$, respectively. The input and output energies of rice production were determined to be 39,333 and $60,341 \mathrm{MJ}^{-1}$ where the fuel energy, with a share of 46 percent, and chemical fertilizers, with a share of 36 percent, represented the highest portions in energy consumption. Moreover, the shares of indirect and non-renewable energies were 51 percent and 89 percent respectively, indicating the big share of fossil energy in the production of rice. The fitted econometrics model, assisted by the Cobb-Douglas production function, signified that the impact of fuel input energy and machinery on yield of rice is significant. The analysis of the sensitivity of the energy of the inputs in this study showed that the highest marginal physical production of inputs pertained to the fuel energy at 0.92 followed by machinery at 0.23 . The economic parameters of rice production including the total cost of production, gross return, net return and the benefit to cost ratio were determined to be $2116,842 \$$.ha ${ }^{-1}, 2071,738 \$$.ha ${ }^{-1}, 1277.914 \$$.ha ${ }^{-1}$ and 1.604 , respectively. The overall conclusion of their research showed that more extensive rice fields (larger than one hectare) demonstrated a better management in energy consumption and performed more successfully [41].

In investigating the efficiency of the consumptive energy, the emission of greenhouse gases and carbon efficiency of rice fields in the Sari County, the energy

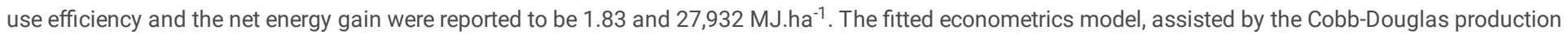
function, showed that the impact of the machinery's input energy and human labor on the yield of the crop is significant. The largest elasticity of production (regression coefficient) for the machinery's input energy was obtained to be 0.64 , showing that with a $1 \%$ increase in the energy consumption of this input, the value of the yield of rice increases by $0.64 \%$. The elasticity of production of human labor input energy was determined to be -0.37 . In other words, with a $1 \%$ increase in the energy consumption of this input, the value of the yield of rice decreases by $0.3 \%$. The analysis of the sensitivity of the energy of seed input, human labor, machinery, diesel fuel, fertilizers and chemicals were reported to be $0.058,-0.992,0.078,0.004,0.027$ and 0.089 , respectively. In other words, with the rise of the consumption of $1 \mathrm{MJ}$ of these inputs, provided that the energy consumption of other inputs remains unchanged, the rice yield changes by 0.058 , $-0.992,0.078,0.004,0.027$ and $0.089 \mathrm{~kg} \mathrm{ha}^{-1}[13]$.

In a study, the input and output energies for the production of three varieties of local, high yield and hybrid rice using two traditional and mechanized cultivation methods in the Mazandaran province were investigated. The energy use efficiency for the production of rice using two traditional and mechanized cultivation methods were expressed to be 1.72 and 1.63 , respectively [1].

Chauhan et al. [5] investigated the improvement of the energy consumption of paddy production in the alluvial regions of India's West Bengal state by taking into account the efficiency of different units and by using the input-oriented BCC and CCR models of the Data Envelopment Analysis method. In this study, input parameters including the consumptive energy of the inputs of human labor, machinery, diesel fuel, seed, organic fertilizers, chemical fertilizers and the yield of the crop as the output were investigated. They reported that $11.6 \%$ of the total consumptive energy in rice production is savable without leading to any decline in the rice yield in case the farmers employ the suggestions presented in the research. They also suggested that better use of consumptive energy in the tillage stage and primary modifications in the machinery can improve the efficiency of energy in the region. They expressed that better use of the tiller and machinery power improves the energy use efficiency, followed by an improvement in the energy productivity in rice production.

Technical efficiency, pure technical efficiency and scale efficiency of rice producers in India were investigated in terms of the quantity of energy consumption in a non-parametric analysis using the Data Envelopment Analysis method as well as BCC and CCR models, and the efficiency of farmers was determined in terms of energy consumption for the production of rice in five different sizes and four different climatic regions. Technical efficiency, pure technical efficiency and scale efficiency for the region 2, which was higher than other regions, were reported to be $0.88,0.91$ and 0.96 respectively. Moreover, out of the total 363 farmers studied in the region, 26 people were efficient in the BCC model and 13 people were efficient in the CCR model [38].

The present study has been carried out with the aim of investigating the energy pattern of consumptive inputs and outputs, optimizing the consumptive energy using the data envelopment analysis method, and to conduct economic assessment and analysis on the emission of greenhouse gases resulting from the production of paddy in the Mazandaran province.

\section{Methods}

\subsection{Agricultural situation of Mazandaran province}

The present research is a field survey carried out in the rice production farms of Mazandaran province of Iran in the year 2018. In the Figure 1, the geographical position of Mazandaran province is illustrated. This province is situated between $35^{\circ} 47^{\prime}$ to $36^{\circ} 35^{\prime}$ northern latitude and $50^{\circ} 34^{\prime}$ to $54^{\circ} 10^{\prime}$ eastern longitude from the prime meridian.

74 percent of lands of Mazandaran are foothill and mountainous while 26 percent are plain. One of the most important features of the province is its high cultivation coefficient, i.e., 1.4, against the national average of 0.7 , which means annually 610,000 hectares of the provincial lands are used for agricultural crops and orchards. In the agricultural year 2017, Mazandaran boasted 213,157 hectares of paddy lands in which 1,261,847 tons of paddy (taking into account the harvesting of ratoon and renewed seedling) were produced, accounting for more than $40 \%$ of rice production nationally.

Representing a $37.5 \%$ share of the harvest area of the lands under cultivation of rice, Mazandaran province ranks first nationally, followed by Guilan Province, which comes second in the countrywide ranking by harvesting 31.2 percent of the nation's rice fields. These two provinces together allocate 68.7 percent of the country's rice cultivation area to themselves[48]. 


\subsection{The methods of data collection and analysis}

The collection of data required in the research was made possible through filling out questionnaires and face-to-face interviews with rice farmers in the Mazandaran province. Other information required were obtained through literature and library research as well as agricultural experts.

In the present research, the simple random sampling technique was used. The population of the research comprised the entire rice-producing farmers in Mazandaran province. The Cochran formula (equation 1) was used to determine the sample size and the number of questionnaires [18, 17, 8].

Equation 1

Were, $\mathrm{n}$ is the sample size, $\mathrm{N}$ is the population size, $\mathrm{S}$ is the population's standard deviation, $\mathrm{d}$ is the favorable probable accuracy and $\mathrm{t}$ is equivalent to 1.96.

Accordingly, the required sample size was determined to be 100 rice fields. The rice production input energies included the energy of labor, machinery and tools, fuel, irrigation water, electricity required to pump water, chemical fertilizers (nitrogen, phosphate, potassium and micronutrients), chemical pesticides (herbicides, insecticides and fungicides) and seeds. The output energy included the energy of paddy and straws. To calculate the input and output energies, the quantity of each consumptive input or output was multiplied by its energy equivalent (energy coefficient). The equivalent values of the consumptive inputs and outputs are presented in the Table 1.

Table 1

\subsection{Calculating the energy indices}

In order to determine the relationship between input and output energies, following indices are defined and employed. These indices are shown in the equations 2 to $9[18,30,33,49]$.

Equation 2

Equation 3

Equation 4

Equation 5

Equation 6

Equation 7

Equation 8

Equation 9

The energy cost is obtained by converting the total input energy into barrel of oil equivalent (BOE) and calculating the price value of crude oil [33]. Every barrel of crude oil is approximately 159 liters, and the energy released from the complete burning there of is 5.8 BTU (British Thermal Unit), or an equivalent of 6.117 gigajoules (GJ).

Researchers consider the energy use efficiency as a criterion for the advancement of technology; therefore, energy use efficiency is the most important index in assessing the energy of agricultural systems. The entire data collected were entered in the excel and the required computations were carried out.

\subsection{Data Envelopment Analysis}

Farrell [11] determined relative efficiency in a production unit like engineering topics with a single input and output. Later on, Charnes et al. [4] improved Farrell method and presented a pattern that could be determined relative efficiency with multiple inputs and outputs. This method was known as DEA. DEA is a relatively new data oriented approach for evaluating the performance of a set of peer entities called decision making units (DMU) which convert multiple inputs into multiple outputs. A great variety of applications of DEA for use in evaluating the performance of different kinds of entities have been seen in the recent years [7].

In DEA, all collected observations are used for measuring efficiency. DEA is making and solving $n$ numbers of models to evaluate $n$ numbers of productivity. In this method, a virtual unit, with the highest relative efficiency, is defined by combining all understudy units. So, inefficiency of units can be identified by comparing them with the virtual unit [43].

In fact, the data envelopment analysis method does not calculate the efficiency of one unit; rather, it calculates the efficiency of one unit against the efficiency of other units and assesses it with other units. The advantages of using the data envelopment analysis method include its comprehensibility, being easy-touse, realistic assessment, the simultaneous assessment of the entire set of factors influencing the model, being needless of weights and pre-determined production function (non-parametric), portraying the best performance situation instead of the favorable situation, the ability to enter multiple inputs and multiple outputs, not requiring the same measurement units for the inputs and outputs and the direct comparison of units with one level or a combination of corresponding collections [19]. 
Efficiency by DEA is defined in three different forms: Technical Efficiency (TE), Pure Technical Efficiency (PTE) and Scale Efficiency (SE) [9]. TE represents the potency of a DMU to produce maximum output given the set of inputs and technology (output-oriented) or to obtain minimizing inputs while maintaining the same level of outputs (input-oriented) [11]. Technical efficiency is a measure evaluating DMU performance relative to that of other DMUs in consideration; it is also called global efficiency.

Pure technical efficiency separates technical and scale efficiencies in other words pure technical efficiency is technical efficiency that has the effect of scale efficiency removed. The advantage of this model is that it compares scale inefficient farms only to efficient farms of a similar size. The main advantage of the VRS model is that scale inefficient farms are only compared to efficient farms of a similar size [2]. The scale efficiency will also be obtained through dividing technical efficiency by pure technical efficiency [34]. In this study, the most comprehensive models of Data Envelopment Analysis, namely the return to constant scale model (CCR) and return to variable scale model (BCC) have been used to calculate efficiency. Each of these models include two input-oriented and output-oriented study directions. This means an inefficient DMU can turn into an efficient unit as a result of the reduction of the levels of input while the output is constant (input-oriented), or conversely, turn into an efficient unit by keeping the level of inputs constant and increasing the values of output (outputoriented) [37]. Choosing between an input-oriented study and an output-oriented study depends on the distinct characteristics of decision-making units being studied. In agricultural studies, input-oriented methods appear to be more appropriate as the number of outputs is limited, while several inputs are used for the production of agricultural crops and there is greater control over the consumption of inputs [31].

The variable return to scale model is used to calculate the pure technical efficiency and constant return to scale is used to calculate the technical efficiency [6].

The technical efficiency of an index is aimed at determining the efficiency of units based on the CCR model. The values of technical efficiency may range between zero and one. Technical efficiency is defined in the Equation 10 [34].

Equation 10

In the Equation $10, u_{1}, u_{2}, \ldots, u_{r}$ are the weights given to outputs for $j^{\text {th }}$ unit $(r=1,2, \ldots, s) ; y_{1}, y_{2}, \ldots, y_{r}$ are the amount of outputs for $j^{\text {th }}$ unit; $v_{1}, v_{2}, \ldots, v_{i}$ are the weights given to inputs for $j^{\text {th }}$ unit $(i=1,2, \ldots, m)$ and $x_{1}, x_{2}, \ldots, x_{i}$ are the amount of inputs for $j^{\text {th }}$ unit, and $j(j=1,2, \ldots, n)$ is the number of the decision-making unit.

In order to solve the Equation 10, linear programming has been used, which is presented in the Equation 11 [16].

Equation 11

Where $\theta$ is the technical efficiency, $u$ is the weight of outputs, $y$ represents the outputs, $v$ is the weight of inputs, $x$ represents the inputs, $n$ is the number of decision-making units, $s$ is the number of outputs and $m$ is the number of inputs.

Moreover, to calculate the pure technical efficiency, the linear programming model has been used which is given in the Equation 12 [34].

Equation 12

Where $z$ and $\mathrm{u}_{0}$ are scalar and free in sign. Eventually, the scale efficiency was calculated through dividing the technical efficiency by pure technical efficiency [9]. The scale efficiency is indication of the impact of the size of decision-making units on the productivity of a system. It shows that some inefficient parts point to the inappropriate size of the decision-making units. If each decision making unit moves toward the best size, it is possible to improve the overall productivity (technical efficiency) to some extent as the level of technology (input) [38]. If a DMU is fully efficient in both CRR and BCC scores, it will operate at the most productive scale size. If a DMU has the full BCC score, but a low CCR score, then it is locally efficient but not globally efficient due to its scale size. Thus, it is reasonable to characterize the scale efficiency of a DMU by the ratio of the two scores [44].

The relationship between scale efficiency, technical efficiency and pure technical efficiency is illustrated in the Equation 13.

Equation 13

In the present study, the efficiency of decision-making unit in paddy fields has been analyzed using the Dea-Solver software and the farms were assessed in terms of the consumption of energy. Subsequently, efficient and inefficient units in the consumption of energy were determined, and eventually the quantity of the consumption of inputs.

\subsection{Greenhouse gas emissions}

Agricultural production necessitates employing a multitude of input materials (fertilizers, biocides, seeds, etc.) and energy carriers (natural gas, diesel fuel, etc.). Production, formulation, storage, distribution of agricultural inputs and their applications with agricultural machinery lead to combustion of fossil fuel, and use of energy from alternative sources which emit $\mathrm{CO}_{2}$ and other greenhouse gases(GHGs) into the atmosphere [26]. Carbon emission coefficients of agricultural inputs were applied to quantify the GHG emissions of rice production. GHG emission coefficients are depicted in Table 2. GHG emissions were worked out by multiplying the input application rate (diesel fuel, chemical fertilizers, machinery, pesticides, electricity and natural gas) by its corresponding emission coefficient.

Table 2

\section{Results And Discussion}


The average consumption of inputs and outputs and their total energy equivalent of paddy production in Mazandaran province are presented in Table 3. The average yield of paddy and rice straw equals to $5253.5 \mathrm{~kg} \mathrm{ha}^{-1}$ and $1899.3 \mathrm{~kg} \mathrm{ha}^{-1}$ respectively.

Table 3

The total input and output energies were determined to be 91061.50 and $100967.95 \mathrm{MJ} \mathrm{ha}^{-1}$. The contribution of consumed inputs to the total input energy is shown in Figure 2. Given the results obtained in this study, diesel fuel was considered to be the most widely used energy input with a share of $41.27 \%$. Despite the limited application of agricultural machinery during growing stage, compared with the extensive application of machinery in the tillage stages, planting and harvesting, the diesel fuel came to be known as the most widely used energy input in the production of rice. After diesel fuel, the largest shares out of the total input energy in the production of paddy belonged to the energy inputs of machinery and chemical fertilizers, standing at $19.63 \%$ and $19.58 \%$, respectively. One of the reasons for the largeness of the share of the consumed energy of machinery input was the using of different tools for the tillage operation. After the inputs of fossil fuel, machinery and chemical fertilizers, the irrigation energy, with a $16.31 \%$ share out of the total input energy, was determined to be an energy-consuming input in the production of paddy in Mazandaran Province. Chemical fertilizers, human labor, seed and animal manure had the smallest share out of the total input energy with values of $1.19 \%, 1.09 \%, 0.9 \%$ and $0.02 \%$, respectively.

Figure 2

The energy indices, i.e., energy use efficiency, energy productivity, specific energy and net energy gain are presented in Table 4.

According to the results obtained, energy use efficiency was estimated to be 1.11 . Energy productivity was calculated to be $0.058 \mathrm{~kg} \mathrm{MJ}^{-1}$. In fact, in order to produce one kilogram of paddy, 17.24 MJ of energy were consumed. Based on the studies, energy use efficiency for the production of rice using two methods of traditional and mechanized cultivation in the Mazandaran province stood at 1.72 and 1.63 respectively. In the same study conducted in Guilan province of Iran, the energy efficiency of rice production was obtained $1.53[1,41]$.

Table 4

The positivity of the net energy demonstrated that the production of rice in studied area was justifiable in terms of energy balance.

In Figure 3, shows the percentages of direct energy and indirect energy as well as renewable and non-renewable energies. The results indicated that with a consumption value of $74368.90 \mathrm{MJ} \mathrm{ha}^{-1}(81.67 \%)$ out of the total energy used, non-renewable energies retained a higher share than the renewable energy with a value of $16692.61 \mathrm{MJ} \mathrm{ha}^{-1}(18.33 \%)$. Results also showed the direct and indirect energy quantities involved in the production of paddy were calculated to be 53451.86 and $37609.64 \mathrm{MJ} \mathrm{ha}^{-1}$, indicating the $58.70 \%$ share of direct energies and $41.30 \%$ share of indirect energies out of the total input energy involved in the paddy production in the province. The reason why the share of direct energy is higher than that of indirect energy is the high percentage of the consumption of irrigation and fuel inputs. According to studies carried out in the Guilan province, the shares of renewable and non-renewable energies from total consumed energy were found to be $11.22 \%$ and $88.78 \%$, respectively. Moreover, $50.7 \%$ and $49.3 \%$ of the input energy represented the shares of indirect and direct energies respectively [41].

Figure 3

\subsection{The results of data envelopment analysis for rice production in the Mazandaran Province}

The results of technical efficiency, pure technical efficiency and scale efficiency of one hundred rice fields studied in the Mazandaran province using the inputoriented data envelopment analysis are given in Table 5. Out of one hundred rice farms studied, in the constant return to scale model, 34 farms retained efficient and 66 farms were inefficient. The farms No. 1, 3, 6, 8, 10, 11, 12, 13, 16, 17, 23, 39, 40, 43, 45, 46, 47, 48, 51, 54, 65, 69, 71, 72, 86, 88, 89, 90, 91, 92, 97, 98,99 and 100 turned out to be efficient in the constant return to scale model. Units boasting a technical efficiency with score 1 were optimal both in terms of management and scale on the level and as a result did not require expanding or limiting their inputs. The most inefficient unit in terms of technical efficiency was determined to be the unit 4, with a technical efficiency of 48.12 . In the variable return to scale model of 85 farms, their pure technical efficiency equaled to 1 and they were efficient, and the other 15 farms had a pure technical efficiency below the unit and were inefficient. The farms No. 9, 14, 15, 28, 38, 41, 49, 53, $67,70,75,76,84,94$ and 96 were inefficient in variable return to scale model. The most inefficient unit in terms of pure technical efficiency was the unit No. 28 with a pure technical efficiency of 92.20 .

34 farms of 100 studied farms retained unit scale efficiency and performed in the most suitable scale size. In these farms, technical efficiency was equal to the pure technical efficiency that represents management efficiency, and in other words, a change in the production scale does not affect their technical efficiency. From 66 technically inefficient farms, 15 farms suffered from management inefficiency (pure technical inefficiency) and scale inefficiency. Therefore, the other 51 farms only had scale inefficiency. This showed the combination of inputs in these units was accurate; however, what has caused them to have efficiency score less than 1, was the lack of performance in the optimal scale. These items require a long-term planning to make the units efficient through moving toward optimal scale.

The results shown in Table 5 demonstrated that out 63 units of 66 technically inefficient farms, have increasing return to scale and 3 units have decreasing return to scale. In units with increasing return to scale, the production unit needed to be enlarged so that efficiency improves while in units with decreasing return to scale the production unit needed to be downsized. In other words, given the definition of technical efficiency, the reduction of production scale for the above mentioned units with decreasing return to scale, leads to a growth of efficiency as a result of which, the efficiency of these units will increase. In the farms where there is a decreasing return to scale, adding for example $1 \%$ to the quantity of the inputs will result in the increasing of the crop to an extent less than $1 \%$. Therefore, the managers of these farms should make efforts to increase their output to input proportion.

Page 6/27 
Table 5

Table 6 shows the average technical efficiency, pure technical efficiency and scale efficiency of the paddy fields studied. The results indicated that the average values of these indices were $0.970,0.996$ and 0.974 , respectively. Moreover, the standard deviations of these indices are shown in Table 6 . The average technical efficiency of one hundred paddy fields investigated was determined to be $97 \%$. In other words, they can reach the threshold of efficiency with 97 percent of production inputs and save three percent of inputs with an increase in their efficiency. As it can be seen from table 6 , the technical efficiency score and scale efficiency range between 0.4812 and 1 and their standard deviation were greater than the pure technical efficiency score, indicating that farmers were not fully aware of the production techniques or did not employ the techniques accurately.

Table 6

In Figure 4, the technical efficiency, pure technical efficiency and scale efficiency of one hundred rice producers studied in the Mazandaran province have been categorized in different groups. It can be seen that in the constant return to scale, 34 units retained absolute efficiency while more than $82 \%$ of the units had a technical efficiency score of more than $95 \%$.

Figure 4

This figure illustrates that after removing the scale inefficiency in the variable return to scale method, 85 paddy fields turned efficient while $98 \%$ of the studied farms had a pure technical efficiency of more than $95 \%$. 34 farms retained scale efficiency and $86 \%$ of the farms had a scale efficiency of more than $95 \%$.

Table 7 shows the benchmark (reference set) for 66 inefficient farms and the number of the replications of 34 efficient units in the benchmark pattern of inefficient farms in the constant return to scale model. It can be observed that although all the efficient farms indicat a technical efficiency of 1 in prioritizing the most efficient rice production units, the farms No. $100,46,13,1,99,47,90,10,6$ and 65 are ranked $1^{\text {st }}$ to $10^{\text {th }}$ respectively with $47,45,43,35,34,25,19,15$, 13 and 12 replications as the reference set.

In the data envelopment analysis method, for each of the inefficient units, one unit or a combination of both or several efficient units are introduced as the pattern. The rest of the units could achieve the optimal level considering the weights (coefficients) given pertaining to each pattern unit. The unit No. 4 found to be the most inefficient unit with an efficiency of $48.12 \%$. Since the pattern units of this unit are the farms No. $1,3,6,13$ and 46 , it should consume, in accordance with the weight coefficients given in the Table $11,0.039,0.185,0.0001,0.173$ and 0.055 of the production factors used in those units in order to become efficient. Therefore, considering the Table 8, unit 4 should lower the quantity of its seed energy, fuel, machinery, chemical fertilizers, animal manure, pesticide, irrigation and labor force by $422.36,11,546.05,3,828.32,8,727.26,0.08,416.45,5,235.06$ and 847.77 MJ ha $^{-1}$ to become an efficient unit. After optimization, the total input energy consumption of unit 4 declines from $58,280.11$ to $27,256.77 \mathrm{MJ} \mathrm{ha}^{-1}$ and a total of $53.23 \%$ of energy would be saved. The fact that unit 4 should achieve maximum efficiency with these values of input in order to become efficient means that this unit should increase its rice production capacity, and for this purpose plant breeding and crop improvement are appropriate.

Table 7

Table 8

The other production units whose efficiencies are less than 100 percent can identify their pattern unit. The units with an analysis like the one given above, can identify the analysis of inputs in order to achieve a certain level of output.

The optimal value of energy consumption and the quantity of energy saving for each of the inputs of rice production are presented in Table 9 . These values have been calculated in terms of the variable return to scale model. The results showed the average quantity of energy consumption under optimal circumstances equals to $86115.829 \mathrm{MJ} \mathrm{ha}^{-1}$, in compared to the status quo which is $4945.675 \mathrm{MJ} \mathrm{ha}^{-1}$ lower. This articulates that by taking into account the recommendations of this study and without reducing the current yield level of rice, it is possible to save $5.43 \%$ of consumed energy.

The highest quantity of saving was observed in the fuel consumption input energy at 2,796.09 $\mathrm{MJ} \mathrm{ha}^{-1}$ followed by the energy of irrigation inputs and chemical fertilizers at 917.23 and $914.47 \mathrm{MJ} \mathrm{ha}^{-1}$. Considering the detrimental environmental impacts of the fuel consumption and chemical fertilizers, the optimization and consumption management of these inputs can result in greater sustainability of rice production in the studied areas in addition to reducing the consumption of energy.

Table 9

In Figure 5, shows the percentage of energy saving for each of the consumptive inputs of rice production out of the total savable energy. As it can be seen frm the figure, the fuel energy, irrigation and chemical fertilizers indicated the highest percentages of energy saving of $\% 56.54, \% 18.55$ and $\% 18.49$, respectively. This demonstrated that in inefficient farms, these inputs were not employed appropriately and it is imperative that a suitable consumption pattern for these inputs is promoted in the areas. Singh et al. [47] investigated the consumption of energy in wheat production in different areas of India. They reported that with the optimal use of energy in the areas, it is possible to increase the performance of wheat between $4.2 \%$ and $22.3 \%$.

Figure 5

The data envelopment analysis technique leads to the optimization of energy indices in the production of rice crop. The results of the optimization of the energy indices in the production of rice are presented in Table 10. As it can be seen, energy efficiency was calculated to be 1.172 under optimal circumstances, which shows a $5.38 \%$ improvement compared to the status quo (1.09). Moreover, the productivity of rice seed under the current and optimal circumstances

Page $7 / 27$ 
was found to be 0.059 and $0.061 \mathrm{~kg} \mathrm{MJ}^{-1}$, respectively, indicating that with the optimization of energy consumption, the quantity of produced crop increases by 3.28 percent per each unit of consumed energy. Evidently, with the optimization of input energy, the share of indirect and non-renewable energies out of the total input energy increases. Moreover, the shares of direct energy and renewable energies have been on a declining course in a reverse manner and this is due to the large share of irrigation energy in improving energy.

Table 10

The detail of the pure technical efficiency (PTE), the current use of energy, and the optimal energy required from different energy sources for the inefficient farmers are given in table 11. Using such data, it is possible to recommend that the decision making could reduce the quantity of input energies by taking into account the operational methods in which the output quantity (yield) remains constant. Therefore, the publication of these results contributes to the improvement of the productivity of energy for the production of rice in the studied area. In the last column of Table 15, the energy saving target ratios (ESTR) for 15 farmers affected by management inefficiency are presented. As can be seen, for the inefficient farmers, ESTR ranged between 0.2 percent (farmers No. 38 ) and 14.19 percent (farmer No. 84). The average energy saving target ratio stood at $5.44 \%$, indicating that among the inefficient farmers, the farmers No. 38 was the best and the farmer No. 84 was the most inefficient.

Table 12 shows the results of the analysis of paddy fields in the input-oriented variable return to scale model for the determination of excess inputs and the slacks of the yield of farms. In this table, it was determined for 56 inefficient combined units to what extent they should reduce the use of excess inputs so that they become efficient. For example, the farm No. 9, with a pure technical efficiency of 0.991 , should first reduce its entire inputs to 99.1 percent and then decrease its consumptive seed input to 230.49 units and its chemical pesticides to 72.16 units to be placed on the BCC efficient threshold. Table 12 shows $71.43 \%$ of paddy fields boast excessive consumption in the use of seed input, as is the case with $73.21 \%$ of farms in the consumption of fuel input, $37.50 \%$ in the use of machinery input, $32.14 \%$ in the use of chemical fertilizers, $19.64 \%$ in the use of animal manure, $28.57 \%$ in the use of pesticides input, $60.71 \%$ in the use of irrigation input and $28.57 \%$ in the use of human labor input.

Table 11

Table 12

\subsection{Economic analysis}

The production costs included the wages of the human labor, land preparation, agricultural inputs, the costs of transplanting, cultivation and harvesting, conversion and processing. In the present study, the conventional average rental fee for each hectare of paddy field amounted to $823.53 \$$ and the conventional interest rate was considered to be $15 \%$. The results of this research showed that the gross production value and the total rice production cost in the Mazandaran province amounted to $3394.776 \$$ ha $^{-1}$ and $2116.862 \$ \mathrm{ha}^{-1}$, and the benefit to cost ratio was estimated to be 1.604 (Table 13 ). The fixed costs comprised $37.5 \%$ and the variable costs comprised \% 62.5 of the total production costs. The net return resulting from the production of rice equaled to $1277.914 \$ \mathrm{ha}^{-1}$, signifying the economic justifiability of the production of rice in the Mazandaran province.

Table 13

In Table 13, the economic productivity of rice production was found to be $1.024 \mathrm{~kg} \mathrm{~S}^{-1}$. The energy intensiveness index showed that on average, per each dollar of rice production costs, $43.017 \mathrm{MJ}$ of energy from different inputs would be supplied. The energy intensiveness value index expresses that on average, for the supplying of $26.824 \mathrm{MJ}$ of energy from different energy inputs to be used, one dollar of revenue would be made. The energy intensity cost index showed that for each kilogram of produced rice, the equivalent value of consumptive energy would be $0.481 \$$ and the energy cost ratio showed that for each unit of rice production cost, the equivalent value of the energy supplied from different inputs to be used in the paddy field equaled 0.492 units. In the research by Pishgar et al. [41] the gross income, gross profit and net profit were obtained to be 4,095.6\$ ha-1, 1,641.98 $\$$ ha $^{-1}$ and $939.71 \$$ ha $^{-1}$, respectively. In their research, Pishgar et al. [41] reported the fixed and changing costs of rice production in the Guilan province to be $702.27 \$$ ha-1 and 2,453.62 $\$$ ha-1, respectively. They also reported the total cost of rice production in the Guilan province to be $3,155.89 \$$ ha-1 and $0.9 \$ \mathrm{~kg}-1$. The benefit to cost ratio equaled 1.3 and the economic productivity of rice production was expressed to be $1.12 \$ \mathrm{~kg}^{-1}$.

\subsection{The results of greenhouse gas emissions of rice production}

The quantities of GHG emissions under real and optimal circumstances are presented in Table 14. The The GHG emissions under current conditions obtained $4,251.33 \mathrm{~kg} \mathrm{CO}_{2}$ eq. ha ${ }^{-1}$, while decreased to $4,146.21 \mathrm{~kg} \mathrm{CO}_{2}$ eq. ha-1 under optimal cultivation system. In other words, GHG emissions would be dropped by $2.7 \%$ if agricultural inputs used for rice production in the studies area were employed efficiently. The largest values of the mitigate of greenhouse gas emissions caused by the electricity, diesel fuel and machinery were obtained to be $35.76,31.01$ and $27.06 \mathrm{~kg} \mathrm{CO}_{2}$ eq. ha-1.

The use of chemical fertilizers (particularly nitrogen fertilizer) more than what is required for the plant leads to the pollution of water and soil at the same time as emitting a great load of greenhouse gas emissions. Moreover, the emissions related to the consumption of diesel fuel have to do with the use of outdated tractors in different agricultural operations, the incompatibility of power capacities in the machinery and tractors and the extensive consumption of energy resulting from intense tillage operations.

The use of appropriate tillage operations such as minimum tillage method and the use of combined machinery would result in the reduction of fuel consumption. Moreover, using new electromotors with a high working safety, together with the farmers' awareness of the real water requirements throughout the different stages of rice production would result in the reduction of greenhouse gas emissions pertaining to the consumptive electricity.

Page $8 / 27$ 
Khakbazan et al. [23] compared the greenhouse emissions in the shifting cultivation of wheat and chickpea crops. On this basis, the entire greenhouse gas emissions in producing one hectare of chickpea and wheat were obtained to be 250 and $768 \mathrm{~kg} \mathrm{CO}_{2}$ eq. ha-1 ${ }^{-1}$, respectively.

Moreover, the proportion of the yield of crops to the total greenhouse gas emissions in the chickpea and wheat crops were estimated to be 12.6 and $3.68 \mathrm{~kg}$ $\left(\mathrm{kg} \mathrm{CO}_{2} \text { eq. }\right)^{-1}$, which was indicative of the higher yield of chickpea as compared to wheat [23].

In a study performed to calculate the greenhouse gas emissions of wheat production in Isfahan province, electricity and nitrogen fertilizer boasted the largest consumptive shares among other inputs with $2,400.7$ (74\%) and $371.2(14 \%) \mathrm{kg} \mathrm{CO}_{2}$ eq. ha ${ }^{-1}$, respectively [28].

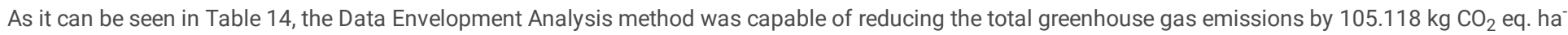

${ }^{1}$. In a study on the reduction of greenhouse gas emissions resulting from strawberry production in the Guilan province, it was shown that the Data

Envelopment Analysis method is capable of reducing $5,774 \mathrm{~kg} \mathrm{CO}_{2}$ eq. ha ${ }^{-1}$ of cultivation of the crop. Moreover, natural gas, with a $65 \%$ share, had the highest potential for the reduction of greenhouse gas emissions [25].

In a study on the amount of the emission of greenhouse gases resulting from cultivating Sorghum in the Sistan region, electricity retained the highest quantity of greenhouse gas emissions with $2,981.27 \mathrm{~kg} \mathrm{CO}_{2}$ eq. ha ${ }^{-1}$ out of a total of $3,746.7 \mathrm{~kg} \mathrm{CO}_{2}$ eq. ha-1 of greenhouse gases. After that, animal manure and diesel fuel retained the highest quantity of greenhouse gas emissions at 277.72 and $258.83 \mathrm{~kg} \mathrm{CO}_{2}$ eq. ha-1.

Table 14

Figure 6 illustrates the share of inputs out of the reduction of greenhouse gas emissions after the improvement of consumption. The electricity input, diesel fuel and machinery had the largest share in the reduction of greenhouse gas emissions resulting from the production of rice at $34.02 \%, 29.5 \%$ and $25.75 \%$, respectively.

Figure 6

In another study the optimization of GHG emissions associated with plant and ratoon farms of sugarcane in the Khuzestan province has been studied using the Data Envelopment Analysis method. Based on the results obtained, the total greenhouse gas emissions in one hectare of plant and ratoon farms amounted to $5,825.25$ and $4,310.7 \mathrm{~kg} \mathrm{CO}_{2}$ eq. where electricity, diesel fuel and nitrogen fertilizer in the plant farms retained the largest shares out of the total greenhouse gas emissions at $74.37 \%, 17.22 \%$ and $4.1 \%$, respectively, while in the ratoon farms, electricity and diesel fuel had the largest shares at $79.29 \%$ and $11.7 \%$. The emission of greenhouse gases in the plant and ratoon farms under optimal circumstances dropped by 633.12 and $110.01 \mathrm{~kg} \mathrm{CO}_{2}$ eq.

\section{Conclusion}

In the present study, the total input and output energies in the rice production process in the Mazandaran province were determined to be $91,061.50$ and $100,967.95 \mathrm{MJ} \mathrm{ha}^{-1}$, respectively. The input of diesel fuel, boasting a $41.27 \%$ share out of the total input energy, is considered to be the most highly consumed energy input. The reason for that is the extensive use of rice machinery and tools in different stages of land preparation, transplanting, cultivation and harvesting of rice due to the special characteristics of paddy production. The energy use efficiency and energy productivity of rice in the Mazandaran province were calculated to be 1.11 and $0.058 \mathrm{~kg} \mathrm{MJ}^{-1}$. The positivity of the net energy demonstrates that the production of rice in the Mazandaran province is justifiable in terms of energy balance. Non-renewable and renewable energies respectively accounted for shares of $81.67 \%$ and $18.33 \%$ out of the total input energy in the production of paddy while direct and indirect energies accounted for shares of $58.70 \%$ and $41.30 \%$. The reason why the share of direct energy is larger than that of indirect energy is the high percentage of the consumption of irrigation inputs and fuel.

The average technical efficiency, pure technical efficiency and scale efficiency of one hundred rice producers were obtained \%97, \%99.6 and \%97.4, respectively. With the improvement of the consumption of inputs, the average energy consumption quantity will be $86,115.829 \mathrm{MJ}$ ha-1 which is $4,945.675 \mathrm{MJ}$ $\mathrm{ha}^{-1}$ less than the status quo. Therefore, considering the recommendations of this study and without reducing the current outputs level, it is possible to save \%5.43 of energy. The highest rate of saving was observed in the fuel input energy valued at 2,796.09 $\mathrm{MJ}^{-1}$, followed by the energy of irrigation inputs and chemical fertilizers with 917.23 and $914.47 \mathrm{MJ} \mathrm{ha}^{-1}$, respectively. Given the detrimental environmental impacts of using fuel and chemical fertilizers, optimization and consumption management of these inputs can lead to increased sustainability in rice production in the area studied as well as reducing the consumption of energy.

Under optimal conditions, the energy efficiency will be 1.172, which shows a $5.38 \%$ increase compared to the current 1.09 value. Moreover, the quantity of energy productivity of rice under the current and optimal circumstances were obtained to be 0.059 and $0.061 \mathrm{~kg} \mathrm{MJ}^{-1}$, respectively. As a result, by optimizing the consumption of energy, the quantity of produced crops increases by $3.28 \%$ for each unit of consumed energy. Evidently, by optimizing the input energy, the share of indirect and non-renewable energies in proportion to the total input energy has increased, and also the share of direct energy and renewable energies in proportion to the reverse state has experienced a decline, which is due to the large share of irrigation energy in improving energy.

The benefit to cost ratio stood at 1.604 and the net return resulting from the rice production equaled to $1277.914 \$$ ha $^{-1}$, signifying the economic justification of the production of rice in the Mazandaran province. On average, per each dollar of rice production cost, $43.017 \mathrm{MJ}$ of energy is consumed from different production inputs in paddy fields. On average, for the entry of $26.824 \mathrm{MJ}$ of energy of different production inputs into the paddy fields of Mazandaran province, one dollar of revenues would be made. Estimates on the energy intensity cost index revealed that the equivalent value of consumed energy for the 
production of each kilogram of crop is $0.481 \$$. The energy ratio cost index showed that for each unit of rice production cost, the equivalent cost of the energy procured from different production units for being used in the rice field equals 0.492 .

With the optimization of the consumption of inputs, the greenhouse gas emissions drop by 2.7 percent. The highest reductions in the greenhouse gas emissions for the electricity input, diesel fuel and machinery were found to be the equivalent of $35.76,31.01$ and $27.06 \mathrm{~kg} \mathrm{CO}{ }_{2}$ eq. ha-1. The inputs of electricity, diesel fuel and machinery, with values of $34.02 \%, 29.5 \%$ and $25.75 \%$ represented the highest shares in the reduction of greenhouse gas emissions.

The optimization of the fuel consumptive energy, agricultural machinery, chemical fertilizers, most notably nitrogen and water for irrigation are among the important pathways to the better management of energy in producing rice in the paddy fields of the province studied. Replacing machinery and new tools with outworn machinery will result in the reduction of energy consumed by the machinery and diesel fuel and result in the lessening of greenhouse gas emissions. In order to reduce the fuel consumption and machinery energy, striking a balance between the machinery and tractor and lessening the extremely high energy resulting from the tillage operation is necessary.

Using suitable tillage methods such as conservation tillage, dry working and using combined machinery result in the reduction of fuel consumed in the province. The inefficiency of irrigation systems, using outworn electromotors and the farmers' unawareness about the plant's genuinely required water are among the reasons for the growth of consumptive energy in the region studied. Therefore, the revision of outworn and dilapidated systems in the irrigation sector and using modern irrigation methods are recommended.

The management of the use of chemical fertilizers, applied research to determine the extent of the need of plants for nutrients during the different stages of growth and determining the appropriate quantity of chemical fertilizers required by the soil using the soil test play a substantial role in reducing the greenhouse gas emissions in the region studied as well as reducing the consumptive energy of this input. In order to reduce the emission of greenhouse gases, efforts should be made to optimize the consumption of chemical fertilizers and replace the organic fertilizers with chemical fertilizers. Reducing the use of chemical pesticides and using of bio-inhibitors instead of chemical pesticides is effective in optimizing the consumption of energy and the reduction of greenhouse gases.

\section{Declarations}

\section{Acknowledgements}

The authors would like to acknowledge the financial support provided by Agricultural Engineering

Research Institute, Karaj, Iran.

\section{Authors' contributions}

All the authors have contributed to the structure, content, and writing of the paper. All authors read and approved the final manuscript.

\section{Funding}

The author's research is funded and supported by Agricultural Engineering Research Institute, Karaj, Iran.

\section{Availability of data and materials}

All the data are provided in the manuscript and additional file.

\section{Competing interests}

The authors declare they have no competing interests.

\section{References}

[1] AghaAlikhani, M., Kazemi-Poshtmasari, H., Habibzadeh, F., 2013. Energy use pattern in rice production: A case study from Mazandaran province, Iran. Energy Conversion and Management, 69: 157-162.

[2] Barnes, A., 2006. Does multi-functionality affect technical efficiency? A non-parametric analysis of the Scottish dairy industry. Journal of Environmental Management, 80(4): 287-94.

[3] Burhan, O., Akcaoz, H., Cemal, F., 2004. Energy input-output analysis in Turkish agriculture. Renewable Energy, 29: 39-51.

[4] Charnes, A., Cooper, W.W., Rhodes, E., 1979. Measuring the efficiency of decision-making units. European Journal of Operational Research, 3(4): 339.

[5] Chauhan, N.S., Mohapatra, P.K.J., Pandey, KP., 2006. Improving energy productivity in paddy production through benchmarking-An application of data envelopment analysis. Energy Conversion and Management, 47: 1063-1085.

[6] Cooper, W.W., Ruiz, J.L., Sirvent, I., 2007. Choosing weights from alternative optimal solutions of dual multiplier models in DEA. European Journal of Operational Research, 180(1): 443-458. 
[7] Cooper, W.W., Seiford, L.M., Zhu, J., 2004. Data envelopment analysis: History, Models, and Interpretations. In: Cooper, W. W., Seiford, L. M. and Zhu, J.(Eds.) Handbook on data envelopment analysis. Springer, US. 1-39.

[8] Cochran, William. G., 1997. Sampling Techniques. Third Edition. John Wiley \& Sons, New York. 428 pp.

[9] Drake, L., Howcroft, B., 1994. Relative efficiency in the branch network of a UK bank: an empirical study. Omega, 22(1): 83-90.

[10] Dyer, J.A., Desjardins, R.L., 2006. Carbon dioxide emissions associated with the manufacturing of tractors and farm machinery in Canada. Biosystems Engineering, 93 (1): 107-118.

[11] Farrell, M.J., 1957. The measurement of productive efficiency. Journal of the Royal Statistical Society, Series A (General), $120(3): 253-290$.

[12] Fartout Enayat, F., Mousavinik, S.M., Asgharipour, M.R., 2017. Evaluation of Energy Use Efficiency, Green House Gases Emission and Economic Analysis of Sorghum Production in Sistan. Journal of Agricultural science and sustainable production, 27(3): 33-43. (In Farsi)

[13] Firouzi, S., Nikkhah, A., Khojastehpour, M., Holden, N.M., 2016. Energy use efficiency, GHG emissions, and carbon efficiency of paddy rice production in Iran. Energy Equipment and Systems, 4(2): 169-176.

[14] Food and Agriculture Organization of United Nations (FAO). 2017. Availble in: http://www.fao.org/faostat/en/

[15] Ghahdarijani, M., Keyhani, A.R., Tabatabaeefar, A., Omid, M., 2009. Evaluation and determination of energy consumption for potato production in various levels of cultivated areas in Isfahan province of Iran (Case study: western of Isfahan province). Journal of Agricultural Sciences and Natural Resources.

Gorgan University of Agricultural Sciences and Natural Resources, 16(1): 183-195. (In Farsi)

[16] Ghasemi-Mobtaker, H., Akram, A., Keyhani, A., Mohammadi, A., 2012a. Optimization of energy required for alfalfa production using data envelopment analysis approach. Energy for Sustainable Development, 16(2): 242-248.

[17] Ghasemi Mobtaker, H., Akram, A., Keyhani, A., 2012b. Energy use and sensitivity analysis of energy inputs for alfalfa production in Iran. Energy for sustainable development, 16(1):84-89.

[18] Ghasemi Mobtaker, H., Mohammadi, A., Rafiee, S., Keyhani, A., Akram, A., 2010. Sensitivity analysis of energy inputs for barley production in Hamedan Province of Iran. Agriculture, Ecosystems and Environment, 137: 367-372

[19] Ghoseiri, K., Mehrno, H., Jafarian Moghaddam, A., 2007. Introduction to Fuzzy Data Envelopment Analysis. Islamic Azad University, Qazvin Branch, Iran. Pp 325. (In Farsi)

[20] Hamedani, S.R., Shabani, Z., Rafiee, S., 2011. Energy inputs and crop yield relationship in potato production in Hamadan province of Iran. Energy, 36(5): 2367-2371.

[21] Hatirli, S., Ozkan, B., Fert, C., 2005. An econometric analysis of energy input-output in Turkish agriculture. Renewable and Sustainable Energy Reviews, 9: 608-623.

[22] Kaab, A., Sharifi, M., Mobli, H., 2019. Analysis and Optimization of Energy Consumption and Greenhouse Gas Emissions in Sugarcane Production Using Data Envelopment Analysis, Iranian Journal of Biosystem Engineering, 50(1):19-30. (In Farsi)

[23] Khakbazan, M., Mohr, R.M., Derksen, D.A., Monreal, M.A., Grant, C.A., Zentner, R.P., Moulin, A.P., McLaren, D.L., Irvine, R.B., Nagy, C.N., 2009. Effects of alternative management practices on the economics, energy and GHG emissions of a wheat-pea cropping system in the Canadian praprairies. Soil \& Tillage Research, 104: 30-38.

[24] Kitani, O., 1999. CIGR Handbook of Agricultural Engineering, volume 5. Energy and Biomass Engineering. ASAE publication, St Joseph, MI.

[25] Khoshnevisan, B., Shariati, H.M., Rafiee, S., Mousazadeh, H., 2014. Comparison of energy consumption and GHG emissions of open field and greenhouse strawberry production. Renewable and Sustainable Energy Reviews 29, 316-324.

[26] Khoshnevisan, B., Rafiee, S., Mousazadeh, H., 2013a. Environmental impact assessment of open field and greenhouse strawberry production. European Journal of Agronomy, 50: 29-37.

[27] Khoshnevisan, B., Rafiee, S., Omid, M., Yousefi, M., Movahedi, M., 2013b. Modeling of energy consumption and GHG (greenhouse gas) emissions in wheat production in Esfahan province of Iran using artificial neural networks. Energy, 52: 333-338.

[28] Khoshnevisan, B., Rafiee, S., Omid, M., Mousazadeh, H., 2013c. Applying data envelopment analysis approach to improve energy efficiency and reduce GHG (greenhouse gas) emission of wheat production. Energy 58, 588-593.

[29] Lal, R., 2004. Carbon emission from farm operations. Environment International, 30 (7): 981-990.

[30] Mandal, K.G., Saha, K.P., Ghosh, P.K., Hati, K.M., Bandyopadhyay, K.K., 2002. Bioenergy and economic analysis of soybean based crop production systems in central India. Biomass Bioenergy, 23(5):337-345. 
[31] Moghimi, M.R., Alasti, B.M., Hadad Drafshi, M.A., 2013. Energy input-output and study on energy use efficiency for wheat production using DEA. International Journal of Agriculture and Crop Sciences. 5(18): 2064-2070.

[32] Mohammadi, A., Rafiee, S., Mohtasebi, S.S., Mousavi, Avval, S.H., Rafiee, S., 2011. Energy efficiency improvement and input cost saving in kiwifruit production using Data Envelopment Analysis approach. Renewable Energy, 36(9): 2573-2579.

[33] Mohammadshirazi, A., Akram, A., Rafiee, S., MousaviAvval, S.H., Bagheri Kalhor, E., 2012. An analysis of energy use and relation between energy inputs and yield in tangerine production. Renewable and Sustainable Energy Reviews, 16: 4515-4521.

[34] Mousavi-Avval, S.H., Rafiee, S., Jafari, A., Mohammadi, A., 2011. Optimization of energy consumption for soybean production using Data Envelopment Analysis (DEA) approach. Applied Energy, 88(11): 3765-3772.

[35] Nabavi-Pelesaraei, A., Hosseinzadeh-Bandbafha, H., Qasemi-Kordkheili, P., Kouchaki-Penchah, H., Riahi-Dorcheh, F., 2016. Applying optimization techniques to improve of energy efficiency and GHG (greenhouse gas) emissions of wheat production. Energy, 103: 672-678.

[36] Nabavi-Pelesaraei, A., Abdi, R., Rafiee, S., Taromi, K., 2014a. Applying data envelopment analysis approach to improve energy efficiency and reduce greenhouse gas emission of rice production. Engineering in Agriculture, Environment and Food. 7(4):155-162.

[37] Nabavi-Pelesaraei, A., Abdi, R., Rafiee, S., Ghasemi Mobtaker, H., 2014b. Optimization of energy required and greenhouse gas emissions analysis for orange producers using data envelopment analysis approach. Journal of Cleaner Production, 65, 311-317.

[38] Nassiri, S.M., Singh, S., 2009. Study on energy use efficiency for paddy crop using data envelopment analysis (DEA) technique. Applied Energy, 86: 13201325.

[39] Ozkan, B., Akcaoz H., Fert, C., 2004. Energy input output analysis in Turkish agriculture. Renewable Energy, 29(1): 39-51.

[40] Pishgar-Komleh, S.H., Ghahderijani, M., Sefeedpari, P., 2012. Energy consumption and CO2 emissions analysis of potato production based on different farm size levels in Iran. Journal of Cleaner Production 33, 183-191.

[41] Pishgar-Komleh, S.H., Sefeedpari, P., Rafiee, S., 2011. Energy and economic analysis of rice production under different farm levels in Guilan province of Iran. Energy, 36: 5824-5831.

[42] Rafiee, S., Mousavi Avval, S.H.M., Mohammadi, A., 2010. Modeling and sensitivity analysis of energy inputs for apple production in Iran. Energy, 35(8): 3301-3306.

[43] Ronald, K.K. Samuel, J.R., 2008. Modeling data envelopment analysis (DEA) efficient location/allocation decisions. Computers and OR, 35 : $457-474$.

[44] Sarlca, K., Or, I., 2007. Efficiency assessment of Turkish power plants using data envelopment analysis. Energy, 32(8): 1484-1499.

[45] Sayin, C., Mencet, M.N., Ozkan, B., 2005. Assessing of energy policies based on Turkish agriculture: current status and some implications. Energy Policy, 33: $2361-2373$.

[46] Sefeedpari, P., Shokoohi, Z., Behzadifar, Y., 2014. Energy use and carbon dioxide emission analysis in sugarcane farms: a survey on Haft-Tappeh Sugarcane Agro-Industrial Company in Iran. Journal of Cleaner Production, 83: 212-219.

[47] Singh, G., Singh, S., Singh, J., 2004. Optimization of energy inputs for wheat crop in Punjab. Energy Conversion and Management, 45: $453-465$.

[48] Statistics Reports of Agriculture (Vol. 1). 2017. Ministry of Jihad-e-Agriculture of Iran. Department of Planning and Economy. Statistics and Information Technology Office. Available from: http://dpe.agri-jahad.ir/portal/Home/ Default. (In Farsi)

[49] Tabatabaie, S.M., H., Rafiee, S., Keyhani, A., Heidari, M.D., 2013. Energy use pattern and sensitivity analysis of energy inputs and input costs for pear production in Iran. Renewable Energy, 51: 7-12.

[50] Yilmaz, I., Akcaoz, H., Ozkan, B., 2005. An analysis of energy use and input costs for cotton productionin Turkey. Renewable Energy, 30 : $145-155$.

[51] Yuan, S., Peng, S., 2017. Input-output energy analysis of rice production in different crop management practices in central China. Energy, $141: 1124-1132$.

\section{Equations}

Due to technical limitations, the equations are only available as a download in the supplemental files section.

\section{Tables}




\begin{tabular}{|c|c|c|c|}
\hline Particulars & Energy equivalent & Unit & References \\
\hline \multicolumn{4}{|l|}{ Inputs } \\
\hline Human Labor & 1.96 & MJ hr-1 & {$[39,50,47]$} \\
\hline Diesel & 56.3 & $\mathrm{MJ} \mathrm{L}^{-1}$ & {$[47]$} \\
\hline \multicolumn{4}{|l|}{ Machinery } \\
\hline Tractor & 138 & $\mathrm{MJ} \mathrm{kg}^{-1}$ & [24] \\
\hline Plow & 180 & $\mathrm{MJ} \mathrm{kg}^{-1}$ & {$[24]$} \\
\hline Sprayer & 129 & $\mathrm{MJ} \mathrm{kg}^{-1}$ & [47] \\
\hline Fertilizer & 129 & $M J k g^{-1}$ & [24] \\
\hline Trailer & 138 & $\mathrm{MJ} \mathrm{kg}^{-1}$ & [24] \\
\hline Combine & 148 & $\mathrm{MJ} \mathrm{kg}^{-1}$ & {$[24]$} \\
\hline Disc harrow & 62.7 & $\mathrm{MJ} \mathrm{kg}^{-1}$ & [47] \\
\hline Leveler & 62.7 & $\mathrm{MJ} \mathrm{kg}^{-1}$ & [47] \\
\hline Subsoiler & 62.7 & $\mathrm{MJ} \mathrm{kg}^{-1}$ & {$[47]$} \\
\hline Electromotor & 64.80 & $\mathrm{MJ} \mathrm{kg}^{-1}$ & {$[47]$} \\
\hline \multicolumn{4}{|l|}{ Chemical fertilizer } \\
\hline Nitrogen $(\mathrm{N})$ & 76.14 & $\mathrm{MJ} \mathrm{kg}^{-1}$ & {$[50]$} \\
\hline Phosphorus $\left(\mathrm{P}_{2} \mathrm{O}_{5}\right)$ & 12.4 & $\mathrm{MJ} \mathrm{kg}^{-1}$ & {$[50]$} \\
\hline Potassium $\left(\mathrm{K}_{2} \mathrm{O}\right)$ & 11.15 & $\mathrm{MJ} \mathrm{kg}{ }^{-1}$ & {$[50]$} \\
\hline Chemicals & 120 & $\mathrm{MJ} \mathrm{kg}^{-1}$ & [30] \\
\hline Rice seed & 14.7 & $\mathrm{MJ} \mathrm{kg}^{-1}$ & {$[39,45]$} \\
\hline Electricity & 11.93 & $\mathrm{MJ} \mathrm{kWh}^{-1}$ & [3] \\
\hline Water & 1.02 & $\mathrm{~m}^{3}$ & [51] \\
\hline FYM & 0.3 & $M J ~ k g-1$ & [39] \\
\hline Transportation & 3.05 & $\mathrm{MJ}(\mathrm{t} . \mathrm{km})^{-1}$ & [24] \\
\hline \multicolumn{4}{|l|}{ Outputs } \\
\hline Paddy rice & 14.7 & $\mathrm{MJ} \mathrm{kg}^{-1}$ & {$[39,45]$} \\
\hline Straw & 12.5 & $\mathrm{MJ} \mathrm{kg}^{-1}$ & {$[39,45]$} \\
\hline
\end{tabular}




\begin{tabular}{|c|c|c|c|}
\hline Input & Unit & $\begin{array}{l}\text { GHG coefficient } \\
\left(\mathrm{kg} \mathrm{CO}_{2} \text { eq } \text { unit }^{-1}\right)\end{array}$ & Reference \\
\hline Machinery & MJ & 0.071 & [10] \\
\hline Diesel & L & 2.76 & [10] \\
\hline \multicolumn{4}{|c|}{ Chemical fertilizer } \\
\hline Nitrogen & $\mathrm{kg}$ & 1.3 & [27] \\
\hline Phosphate & $\mathrm{kg}$ & 0.2 & [27] \\
\hline Potassium & $\mathrm{kg}$ & 0.2 & [27] \\
\hline \multicolumn{4}{|l|}{ Chemicals } \\
\hline Insecticide & $\mathrm{kg}$ & 6.3 & [40] \\
\hline Herbicide & $\mathrm{kg}$ & 5.1 & [29] \\
\hline Fungicide & $\mathrm{kg}$ & 3.9 & [29] \\
\hline Electricity & kWh & 0.608 & [27] \\
\hline
\end{tabular}

\begin{tabular}{|c|c|c|}
\hline Particulars(Unit) & $\begin{array}{l}\text { Amount per hectare } \\
\left(\text { Unit ha }^{-1}\right)\end{array}$ & $\begin{array}{l}\text { Total energy equivalent } \\
\left(\mathrm{MJ} \mathrm{ha}^{-1}\right)\end{array}$ \\
\hline \multicolumn{3}{|l|}{ Inputs } \\
\hline Human labor (h) & 508.4 & 996.47 \\
\hline Machinery(h) & 285.1 & 17874.88 \\
\hline Diesel (L) & 667.4 & 37583.23 \\
\hline Seed $(\mathrm{kg})$ & 56.1 & 823.97 \\
\hline Chemicals (kg) & & 1081.89 \\
\hline Herbicides (kg) & 2.2 & 523.98 \\
\hline Fungicides (kg) & 0.0103 & 2.230 \\
\hline Insecticides (kg) & 5.5 & 555.69 \\
\hline Chemical fertilizer (kg) & & 17828.88 \\
\hline Nitrogen (kg) & 233.7 & 15454.97 \\
\hline Phosphorus (kg) & 116.8 & 1453.24 \\
\hline Potassium (kg) & 82.6 & 920.67 \\
\hline Farmyard manure $(\mathrm{kg})$ & 64.2 & 19.44 \\
\hline Water $\left(\mathrm{m}^{3}\right)$ & 14561.5 & 14852.71 \\
\hline Total energy input(MJ) & & 91061.50 \\
\hline \multicolumn{3}{|l|}{ Outputs } \\
\hline Straw (kg) & 1899.3 & 23741.51 \\
\hline Paddy rice $(\mathrm{kg})$ & 5253.5 & 77226.44 \\
\hline Total energy output (MJ) & & 100967.95 \\
\hline
\end{tabular}




\begin{tabular}{|lcc|}
\hline \multicolumn{3}{|l|}{ Table 4. Energy input-output ratio in rice production of Mazandran province, Iran. } \\
\hline Items & Unit & Value \\
\hline Energy use efficiency & - & 1.11 \\
\hline Energy productivity & $\mathrm{Kg} \mathrm{MJ}^{-1}$ & 0.059 \\
\hline Specific energy & $\mathrm{MJ} \mathrm{kg}^{-1}$ & 17.24 \\
\hline Net energy & $\mathrm{MJ} \mathrm{ha}^{-1}$ & 9906.45 \\
\hline
\end{tabular}

Page 15/27 


\begin{tabular}{|c|c|c|c|c|c|c|c|c|c|}
\hline $\begin{array}{l}\text { Farm } \\
\text { No. }\end{array}$ & $\begin{array}{l}\text { Technical } \\
\text { efficiency } \\
\text { (TE) }\end{array}$ & $\begin{array}{l}\text { Pure technical } \\
\text { efficiency (PTE) }\end{array}$ & $\begin{array}{l}\text { Scale } \\
\text { efficiency } \\
\text { (SE) }\end{array}$ & $\begin{array}{l}\text { Retum to } \\
\text { scale (RTS) }\end{array}$ & $\begin{array}{l}\text { Farm } \\
\text { No. }\end{array}$ & $\begin{array}{l}\text { Technical } \\
\text { efficiency } \\
\text { (TE) }\end{array}$ & $\begin{array}{l}\text { Pure technical } \\
\text { efficiency (PTE) }\end{array}$ & $\begin{array}{l}\text { Scale } \\
\text { efficiency } \\
\text { (SE) }\end{array}$ & $\begin{array}{l}\text { Return to } \\
\text { scale (RTS) }\end{array}$ \\
\hline 1 & 1.00 & 1.00 & 1.00 & Constant & 51 & 1.00 & 1.00 & 1.00 & Constant \\
\hline 2 & 0.95 & 1.00 & 0.95 & Increasing & 52 & 0.95 & 1.00 & 0.95 & Increasing \\
\hline 3 & 1.00 & 1.00 & 1.00 & Constant & 53 & 0.990 & 0.998 & 0.993 & Increasing \\
\hline 4 & 0.48 & 1.00 & 0.48 & Increasing & 54 & 1.00 & 1.00 & 1.00 & Constant \\
\hline 5 & 0.94 & 1.00 & 0.94 & Increasing & 55 & 0.99 & 1.00 & 0.99 & Increasing \\
\hline 6 & 1.00 & 1.00 & 1.00 & Constant & 56 & 0.98 & 1.00 & 0.98 & Increasing \\
\hline 7 & 0.996 & 1.00 & 0.996 & Increasing & 57 & 0.98 & 1.00 & 0.98 & Increasing \\
\hline 8 & 1.00 & 1.00 & 1.00 & Constant & 58 & 0.98 & 1.00 & 0.98 & Increasing \\
\hline 9 & 0.98 & 0.99 & 0.99 & Increasing & 59 & 0.98 & 1.00 & 0.98 & Increasing \\
\hline 10 & 1.00 & 1.00 & 1.00 & Constant & 60 & 0.99 & 1.00 & 0.99 & Increasing \\
\hline 11 & 1.00 & 1.00 & 1.00 & Constant & 61 & 0.97 & 1.00 & 0.97 & Increasing \\
\hline 12 & 1.00 & 1.00 & 1.00 & Constant & 62 & 0.97 & 1.00 & 0.97 & Increasing \\
\hline 13 & 1.00 & 1.00 & 1.00 & Constant & 63 & 0.97 & 1.00 & 0.97 & Increasing \\
\hline 14 & 0.990 & 0.995 & 0.996 & Increasing & 64 & 0.96 & 1.00 & 0.96 & Increasing \\
\hline 15 & 0.98 & 0.99 & 0.99 & Increasing & 65 & 1.00 & 1.00 & 1.00 & Constant \\
\hline 16 & 1.00 & 1.00 & 1.00 & Constant & 66 & 0.96 & 1.00 & 0.96 & Increasing \\
\hline 17 & 1.00 & 1.00 & 1.00 & Constant & 67 & 0.951 & 0.952 & 0.999 & Increasing \\
\hline 18 & 0.96 & 1.00 & 0.96 & Increasing & 68 & 0.95 & 1.00 & 0.95 & Increasing \\
\hline 19 & 0.97 & 1.00 & 0.97 & Increasing & 69 & 1.00 & 1.00 & 1.00 & Constant \\
\hline 20 & 0.97 & 1.00 & 0.97 & Increasing & 70 & 0.98 & 0.99 & 0.99 & Decreasing \\
\hline 21 & 0.98 & 1.00 & 0.98 & Increasing & 71 & 1.00 & 1.00 & 1.00 & Constant \\
\hline 22 & 0.95 & 1.00 & 0.95 & Increasing & 72 & 1.00 & 1.00 & 1.00 & Constant \\
\hline 23 & 1.00 & 1.00 & 1.00 & Constant & 73 & 0.98 & 1.00 & 0.98 & Increasing \\
\hline 24 & 0.95 & 1.00 & 0.95 & Increasing & 74 & 0.99 & 1.00 & 0.99 & Increasing \\
\hline 25 & 0.98 & 1.00 & 0.98 & Increasing & 75 & 0.947 & 0.948 & 0.999 & Decreasing \\
\hline 26 & 0.97 & 1.00 & 0.97 & Increasing & 76 & 0.950 & 0.951 & 0.999 & Decreasing \\
\hline 27 & 0.88 & 1.00 & 0.88 & Increasing & 77 & 0.95 & 1.00 & 0.95 & Increasing \\
\hline 28 & 0.88 & 0.92 & 0.95 & Increasing & 78 & 0.96 & 1.00 & 0.96 & Increasing \\
\hline 29 & 0.96 & 1.00 & 0.96 & Increasing & 79 & 0.95 & 1.00 & 0.95 & Increasing \\
\hline 30 & 0.95 & 1.00 & 0.95 & Increasing & 80 & 0.94 & 1.00 & 0.94 & Increasing \\
\hline 31 & 0.94 & 1.00 & 0.94 & Increasing & 81 & 0.96 & 1.00 & 0.96 & Increasing \\
\hline 32 & 0.92 & 1.00 & 0.92 & Increasing & 82 & 0.97 & 1.00 & 0.97 & Increasing \\
\hline 33 & 0.98 & 1.00 & 0.98 & Increasing & 83 & 0.96 & 1.00 & 0.96 & Increasing \\
\hline 34 & 0.93 & 1.00 & 0.93 & Increasing & 84 & 0.95 & 0.95 & 0.99 & Increasing \\
\hline 35 & 0.90 & 1.00 & 0.90 & Increasing & 85 & 0.97 & 1.00 & 0.97 & Increasing \\
\hline 36 & 0.97 & 1.00 & 0.97 & Increasing & 86 & 1.00 & 1.00 & 1.00 & Constant \\
\hline 37 & 0.92 & 1.00 & 0.92 & Increasing & 87 & 0.98 & 1.00 & 0.98 & Increasing \\
\hline 38 & 0.961 & 0.998 & 0.963 & Increasing & 88 & 1.00 & 1.00 & 1.00 & Constant \\
\hline 39 & 1.00 & 1.00 & 1.00 & Constant & 89 & 1.00 & 1.00 & 1.00 & Constant \\
\hline 40 & 1.00 & 1.00 & 1.00 & Constant & 90 & 1.00 & 1.00 & 1.00 & Constant \\
\hline 41 & 0.95 & 0.98 & 0.97 & Increasing & 91 & 1.00 & 1.00 & 1.00 & Constant \\
\hline
\end{tabular}




\begin{tabular}{|c|c|c|c|c|c|c|c|c|c|}
\hline 42 & 0.94 & 1.00 & 0.94 & Increasing & 92 & 1.00 & 1.00 & 1.00 & Constant \\
\hline 43 & 1.00 & 1.00 & 1.00 & Constant & 93 & 0.99 & 1.00 & 0.99 & Increasing \\
\hline 44 & 0.97 & 1.00 & 0.97 & Increasing & 94 & 0.95 & 0.98 & 0.98 & Increasing \\
\hline 45 & 1.00 & 1.00 & 1.00 & Constant & 95 & 0.99 & 1.00 & 0.99 & Increasing \\
\hline 46 & 1.00 & 1.00 & 1.00 & Constant & 96 & 0.975 & 0.976 & 0.999 & Increasing \\
\hline 47 & 1.00 & 1.00 & 1.00 & Constant & 97 & 1.00 & 1.00 & 1.00 & Constant \\
\hline 48 & 1.00 & 1.00 & 1.00 & Constant & 98 & 1.00 & 1.00 & 1.00 & Constant \\
\hline 49 & 0.992 & 0.995 & 0.998 & Increasing & 99 & 1.00 & 1.00 & 1.00 & Constant \\
\hline 50 & 0.95 & 1.00 & 0.95 & Increasing & 100 & 1.00 & 1.00 & 1.00 & Constant \\
\hline Average & 0.970 & 0.996 & 0.974 & & & & & & \\
\hline
\end{tabular}

\begin{tabular}{|lllll|}
\hline \multicolumn{4}{|c|}{ Table 6. Average of efficiency items for rice producers of Mazandaran province, Iran. } \\
\hline Particular & Average & Min & Max & SD \\
\hline TE & 0.970 & 0.4812 & 1 & 0.0562 \\
\hline PTE & 0.996 & 0.9221 & 1 & 0.0128 \\
SE & 0.974 & 0.4812 & 1 & 0.0557 \\
\hline
\end{tabular}




\begin{tabular}{|c|c|c|c|c|c|c|c|c|c|c|c|c|c|}
\hline \multirow{2}{*}{$\begin{array}{l}\text { Farm No. } \\
1\end{array}$} & \multirow{2}{*}{$\begin{array}{l}\text { Frequency in } \\
\text { refrence set } \\
35\end{array}$} & \multicolumn{12}{|c|}{ Benchmarks } \\
\hline & & $(1.000)$ & 1 & & & & & & & & & & \\
\hline 2 & - & $(0.059)$ & 1 & $(0.871)$ & 3 & $(0.000)$ & 6 & & & & & & \\
\hline 3 & 8 & $(1.000)$ & 3 & & & & & & & & & & \\
\hline 4 & - & $(0.039)$ & 1 & $(0.185)$ & 3 & $(0.000)$ & 6 & $(0.173)$ & 13 & $(0.055)$ & 46 & (0.019) & 86 \\
\hline 5 & - & $(0.027)$ & 1 & $(0.408)$ & 3 & $(0.000)$ & 6 & $(0.328)$ & 13 & $(0.118)$ & 46 & $(0.041)$ & 86 \\
\hline 6 & 13 & $(1.000)$ & 6 & & & & & & & & & & \\
\hline 7 & - & $(0.084)$ & 1 & $(0.647)$ & 8 & $(0.164)$ & 10 & $(0.052)$ & 46 & $(0.018)$ & 99 & $(0.004)$ & 100 \\
\hline 8 & 3 & $(1.000)$ & 8 & & & & & & & & & & \\
\hline 9 & - & $(0.357)$ & 6 & $(0.349)$ & 8 & $(0.161)$ & 10 & $(0.003)$ & 11 & $(0.052)$ & 46 & $(0.048)$ & 69 \\
\hline 10 & 15 & $(1.000)$ & 10 & & & & & & & & & & \\
\hline 11 & 5 & $(1.000)$ & 11 & & & & & & & & & & \\
\hline 12 & 1 & $(1.000)$ & 12 & & & & & & & & & & \\
\hline 13 & 43 & $(1.000)$ & 13 & & & & & & & & & & \\
\hline 14 & - & $(0.097)$ & 1 & $(0.008)$ & 6 & $(0.051)$ & 11 & $(0.726)$ & 12 & $(0.014)$ & 13 & $(0.083)$ & 47 \\
\hline 15 & - & $(0.096)$ & 1 & $(0.839)$ & 16 & $(0.055)$ & 86 & & & & & & \\
\hline 16 & 5 & $(1.000)$ & 16 & & & & & & & & & & \\
\hline 17 & 1 & $(1.000)$ & 17 & & & & & & & & & & \\
\hline 18 & - & $(0.168)$ & 1 & $(0.614)$ & 16 & $(0.113)$ & 47 & $(0.066)$ & 100 & & & & \\
\hline 19 & - & $(0.196)$ & 1 & $(0.581)$ & 16 & $(0.158)$ & 47 & $(0.037)$ & 100 & & & & \\
\hline 20 & - & $(0.137)$ & 1 & $(0.166)$ & 16 & $(0.454)$ & 17 & $(0.170)$ & 47 & $(0.042)$ & 86 & & \\
\hline 21 & - & $(0.422)$ & 1 & $(0.059)$ & 3 & $(0.000)$ & 6 & $(0.027)$ & 13 & $(0.454)$ & 47 & $(0.005)$ & 86 \\
\hline 22 & - & $(0.433)$ & 1 & $(0.058)$ & 3 & $(0.006)$ & 13 & $(0.380)$ & 47 & $(0.007)$ & 65 & $(0.066)$ & 100 \\
\hline 23 & 3 & $(1.000)$ & 23 & & & & & & & & & & \\
\hline 24 & - & $(0.411)$ & 1 & $(0.026)$ & 16 & $(0.483)$ & 47 & $(0.028)$ & 86 & & & & \\
\hline 25 & - & $(0.055)$ & 1 & $(0.814)$ & 23 & $(0.041)$ & 43 & $(0.019)$ & 45 & $(0.045)$ & 65 & & \\
\hline 26 & - & $(0.264)$ & 1 & $(0.382)$ & 23 & $(0.224)$ & 47 & $(0.047)$ & 65 & $(0.056)$ & 100 & & \\
\hline 27 & - & $(0.010)$ & 1 & $(0.325)$ & 13 & $(0.325)$ & 46 & $(0.220)$ & 86 & & & & \\
\hline 28 & - & $(0.004)$ & 1 & $(0.542)$ & 6 & $(0.010)$ & 8 & $(0.274)$ & 46 & $(0.012)$ & 99 & $(0.106)$ & 100 \\
\hline 29 & - & $(0.340)$ & 1 & $(0.076)$ & 3 & $(0.009)$ & 13 & $(0.371)$ & 47 & $(0.033)$ & 51 & $(0.006)$ & 65 \\
\hline 30 & - & $(0.364)$ & 1 & $(0.082)$ & 23 & $(0.113)$ & 47 & $(0.255)$ & 65 & $(0.000)$ & 69 & $(0.128)$ & 86 \\
\hline 31 & - & $(0.365)$ & 1 & $(0.013)$ & 13 & $(0.040)$ & 46 & $(0.263)$ & 47 & $(0.071)$ & 51 & $(0.010)$ & 65 \\
\hline 32 & - & $(0.299)$ & 1 & $(0.057)$ & 13 & $(0.084)$ & 46 & $(0.293)$ & 47 & $(0.184)$ & 100 & & \\
\hline 33 & - & $(0.306)$ & 1 & $(0.074)$ & 43 & $(0.196)$ & 47 & $(0.251)$ & 65 & $(0.000)$ & 69 & $(0.111)$ & 86 \\
\hline 34 & - & $(0.359)$ & 1 & $(0.066)$ & 13 & $(0.132)$ & 46 & $(0.007)$ & 47 & $(0.162)$ & 88 & $(0.000)$ & 91 \\
\hline 35 & - & $(0.250)$ & 1 & $(0.000)$ & 6 & $(0.042)$ & 13 & $(0.083)$ & 46 & $(0.300)$ & 47 & $(0.048)$ & 51 \\
\hline 36 & - & $(0.214)$ & 1 & $(0.259)$ & 43 & $(0.241)$ & 47 & $(0.145)$ & 65 & $(0.000)$ & 69 & $(0.071)$ & 86 \\
\hline 37 & - & $(0.209)$ & 1 & $(0.050)$ & 13 & $(0.130)$ & 46 & $(0.348)$ & 47 & $(0.167)$ & 100 & & \\
\hline 38 & - & $(0.169)$ & 1 & $(0.050)$ & 40 & $(0.230)$ & 43 & $(0.385)$ & 47 & $(0.046)$ & 69 & $(0.052)$ & 86 \\
\hline 39 & 0 & $(1.000)$ & 39 & & & & & & & & & & \\
\hline 40 & 5 & $(1.000)$ & 40 & & & & & & & & & & \\
\hline 41 & - & $(0.047)$ & 1 & $(0.283)$ & 6 & $(0.130)$ & 40 & $(0.082)$ & 43 & $(0.207)$ & 46 & (0.129) & 99 \\
\hline
\end{tabular}




\begin{tabular}{|c|c|c|c|c|c|c|c|c|c|c|c|c|c|}
\hline 42 & - & $(0.102)$ & 1 & $(0.000)$ & 6 & $(0.078)$ & 13 & $(0.177)$ & 43 & $(0.154)$ & 46 & $(0.282)$ & 51 \\
\hline 43 & 7 & $(1.000)$ & 43 & & & & & & & & & & \\
\hline 44 & - & $(0.000)$ & 10 & $(0.123)$ & 13 & $(0.513)$ & 43 & $(0.175)$ & 46 & $(0.094)$ & 99 & $(0.060)$ & 100 \\
\hline 45 & 1 & $(1.000)$ & 45 & & & & & & & & & & \\
\hline 46 & 45 & $(1.000)$ & 46 & & & & & & & & & & \\
\hline 47 & 25 & $(1.000)$ & 47 & & & & & & & & & & \\
\hline 48 & 0 & $(1.000)$ & 48 & & & & & & & & & & \\
\hline 49 & - & $(0.067)$ & 13 & $(0.065)$ & 46 & $(0.723)$ & 47 & (0.118) & 92 & $(0.016)$ & 100 & & \\
\hline 50 & - & $(0.233)$ & 13 & $(0.298)$ & 46 & $(0.010)$ & 47 & $(0.124)$ & 88 & $(0.107)$ & 90 & $(0.173)$ & 100 \\
\hline 51 & 5 & $(1.000)$ & 51 & & & & & & & & & & \\
\hline 52 & - & $(0.000)$ & 10 & $(0.251)$ & 13 & $(0.241)$ & 46 & $(0.043)$ & 47 & $(0.146)$ & 90 & $(0.098)$ & 99 \\
\hline 53 & - & $(0.024)$ & 10 & $(0.113)$ & 11 & $(0.207)$ & 46 & $(0.537)$ & 69 & $(0.071)$ & 90 & $(0.012)$ & 99 \\
\hline 54 & 0 & $(1.000)$ & 54 & & & & & & & & & & \\
\hline 55 & - & $(0.000)$ & 10 & $(0.247)$ & 13 & $(0.237)$ & 46 & $(0.103)$ & 47 & $(0.065)$ & 90 & $(0.290)$ & 99 \\
\hline 56 & - & $(0.248)$ & 13 & $(0.291)$ & 46 & $(0.190)$ & 90 & $(0.249)$ & 100 & & & & \\
\hline 57 & - & $(0.253)$ & 13 & $(0.276)$ & 46 & $(0.013)$ & 88 & $(0.173)$ & 90 & $(0.267)$ & 100 & & \\
\hline 58 & - & $(0.253)$ & 13 & $(0.273)$ & 46 & $(0.176)$ & 90 & $(0.075)$ & 99 & $(0.206)$ & 100 & & \\
\hline 59 & - & $(0.246)$ & 13 & $(0.282)$ & 46 & $(0.175)$ & 90 & $(0.279)$ & 100 & & & & \\
\hline 60 & - & $(0.000)$ & 10 & $(0.251)$ & 13 & $(0.256)$ & 46 & $(0.023)$ & 47 & $(0.124)$ & 90 & $(0.209)$ & 99 \\
\hline 61 & - & $(0.000)$ & 10 & $(0.296)$ & 13 & $(0.163)$ & 46 & $(0.111)$ & 90 & $(0.242)$ & 99 & $(0.159)$ & 100 \\
\hline 62 & - & $(0.293)$ & 13 & $(0.162)$ & 46 & $(0.110)$ & 90 & $(0.056)$ & 98 & $(0.137)$ & 99 & $(0.217)$ & 100 \\
\hline 63 & - & $(0.274)$ & 13 & $(0.183)$ & 46 & $(0.127)$ & 90 & $(0.089)$ & 98 & $(0.294)$ & 100 & & \\
\hline 64 & - & $(0.284)$ & 13 & $(0.153)$ & 46 & $(0.098)$ & 90 & $(0.118)$ & 98 & $(0.151)$ & 99 & $(0.155)$ & 100 \\
\hline 65 & 12 & $(1.000)$ & 65 & & & & & & & & & & \\
\hline 66 & - & $(0.156)$ & 13 & $(0.111)$ & 46 & $(0.041)$ & 47 & $(0.277)$ & 65 & $(0.343)$ & 99 & $(0.030)$ & 100 \\
\hline 67 & - & $(0.028)$ & 6 & $(0.170)$ & 10 & $(0.033)$ & 40 & $(0.142)$ & 46 & (0.009) & 47 & $(0.258)$ & 72 \\
\hline 68 & - & $(0.266)$ & 13 & $(0.097)$ & 46 & $(0.113)$ & 90 & $(0.217)$ & 98 & $(0.014)$ & 99 & $(0.245)$ & 100 \\
\hline 69 & 7 & $(1.000)$ & 69 & & & & & & & & & & \\
\hline 70 & & $(0.027)$ & 6 & $(0.131)$ & 10 & $(0.022)$ & 11 & $(0.170)$ & 40 & $(0.024)$ & 46 & $(0.049)$ & 51 \\
\hline 71 & 0 & $(1.000)$ & 71 & & & & & & & & & & \\
\hline 72 & 1 & $(1.000)$ & 72 & & & & & & & & & & \\
\hline 73 & - & $(0.147)$ & 1 & $(0.022)$ & 3 & $(0.141)$ & 13 & $(0.024)$ & 65 & $(0.644)$ & 99 & & \\
\hline 74 & - & $(0.152)$ & 1 & $(0.036)$ & 3 & $(0.121)$ & 13 & $(0.029)$ & 65 & (0.005) & 90 & $(0.647)$ & 99 \\
\hline 75 & - & $(0.161)$ & 1 & $(0.155)$ & 10 & $(0.228)$ & 91 & (0.199) & 99 & $(0.262)$ & 100 & & \\
\hline 76 & - & $(0.126)$ & 6 & $(0.253)$ & 11 & $(0.004)$ & 40 & $(0.035)$ & 46 & $(0.597)$ & 99 & $(0.004)$ & 100 \\
\hline 77 & - & $(0.031)$ & 1 & $(0.211)$ & 13 & $(0.374)$ & 99 & $(0.332)$ & 100 & & & & \\
\hline 78 & - & $(0.052)$ & 1 & $(0.162)$ & 13 & $(0.066)$ & 46 & (0.519) & 99 & $(0.166)$ & 100 & & \\
\hline 79 & - & $(0.007)$ & 1 & $(0.170)$ & 13 & $(0.090)$ & 46 & $(0.648)$ & 99 & $(0.034)$ & 100 & & \\
\hline 80 & - & $(0.207)$ & 13 & $(0.000)$ & 46 & $(0.081)$ & 98 & $(0.166)$ & 99 & $(0.488)$ & 100 & & \\
\hline 81 & - & $(0.164)$ & 13 & $(0.104)$ & 46 & $(0.080)$ & 98 & $(0.551)$ & 99 & $(0.060)$ & 100 & & \\
\hline 82 & - & $(0.135)$ & 13 & $(0.112)$ & 46 & $(0.039)$ & 65 & $(0.681)$ & 99 & & & & \\
\hline 83 & - & $(0.140)$ & 13 & $(0.115)$ & 46 & $(0.183)$ & 98 & $(0.401)$ & 99 & $(0.126)$ & 100 & & \\
\hline 84 & - & $(0.033)$ & 1 & $(0.126)$ & 10 & $(0.100)$ & 46 & $(0.568)$ & 99 & $(0.153)$ & 100 & & \\
\hline 85 & - & $(0.000)$ & 10 & $(0.113)$ & 13 & $(0.097)$ & 46 & $(0.565)$ & 99 & $(0.185)$ & 100 & & \\
\hline
\end{tabular}




\begin{tabular}{|c|c|c|c|c|c|c|c|c|c|c|c|c|c|}
\hline 86 & 11 & $(1.000)$ & 86 & & & & & & & & & & \\
\hline 87 & - & $(0.000)$ & 10 & $(0.078)$ & 13 & $(0.079)$ & 46 & $(0.620)$ & 99 & $(0.182)$ & 100 & & \\
\hline 88 & 3 & $(1.000)$ & 88 & & & & & & & & & & \\
\hline 89 & 0 & $(1.000)$ & 89 & & & & & & & & & & \\
\hline 90 & 19 & $(1.000)$ & 90 & & & & & & & & & & \\
\hline 91 & 2 & $(1.000)$ & 91 & & & & & & & & & & \\
\hline 92 & 1 & $(1.000)$ & 92 & & & & & & & & & & \\
\hline 93 & - & $(0.029)$ & 13 & (0.103) & 46 & $(0.085)$ & 90 & $(0.023)$ & 98 & $(0.424)$ & 99 & $(0.326)$ & 100 \\
\hline 94 & - & $(0.027)$ & 13 & $(0.083)$ & 46 & $(0.168)$ & 90 & $(0.689)$ & 100 & & & & \\
\hline 95 & - & $(0.007)$ & 13 & $(0.063)$ & 46 & $(0.124)$ & 90 & $(0.174)$ & 98 & $(0.616)$ & 100 & & \\
\hline 96 & - & $(0.064)$ & 10 & $(0.069)$ & 90 & $(0.700)$ & 99 & $(0.165)$ & 100 & & & & \\
\hline 97 & 0 & $(1.000)$ & 97 & & & & & & & & & & \\
\hline 98 & 9 & $(1.000)$ & 98 & & & & & & & & & & \\
\hline 99 & 34 & $(1.000)$ & 99 & & & & & & & & & & \\
\hline 100 & 47 & $(1.000)$ & 1 & & & & & & & & & & \\
\hline
\end{tabular}

\begin{tabular}{|lllll|}
\hline \multicolumn{3}{|l|}{$\begin{array}{l}\text { Table 8. Optimization of energy consumption for rice farm number } 4 \\
\text { (based on CCR input oriented model) }\end{array}$} & \\
\hline Input & $\begin{array}{l}\text { Actual energy } \\
\left.\text { (MJ ha }{ }^{-1}\right)\end{array}$ & $\begin{array}{l}\text { Target energy } \\
\left(\mathrm{MJ} \mathrm{ha}^{-1}\right)\end{array}$ & $\begin{array}{l}\text { Energy saving target } \\
\left(\mathrm{MJ} \mathrm{ha}^{-1}\right)\end{array}$ & $\begin{array}{l}\text { Energy saving target ratio } \\
(\%)\end{array}$ \\
\hline Seed & 810.12 & 387.76 & 422.36 & 52.14 \\
\hline Diesel & 22205.12 & 10659.06 & 11546.05 & 52 \\
\hline Machinery & 7348.58 & 3520.26 & 3828.32 & 52.1 \\
\hline Fertilizers & 15407.32 & 6680.06 & 8727.26 & 56.64 \\
\hline FYM & 0.15 & 0.07 & 0.08 & 52.08 \\
\hline Chemicals & 799.92 & 383.47 & 416.45 & 52.06 \\
\hline Irrigation & 10075.22 & 4840.16 & 5235.06 & 51.96 \\
\hline Human labor & 1633.69 & 785.92 & 847.77 & 51.89 \\
\hline Total energy & 58280.11 & 27256.77 & 31023.35 & 53.23 \\
\hline
\end{tabular}




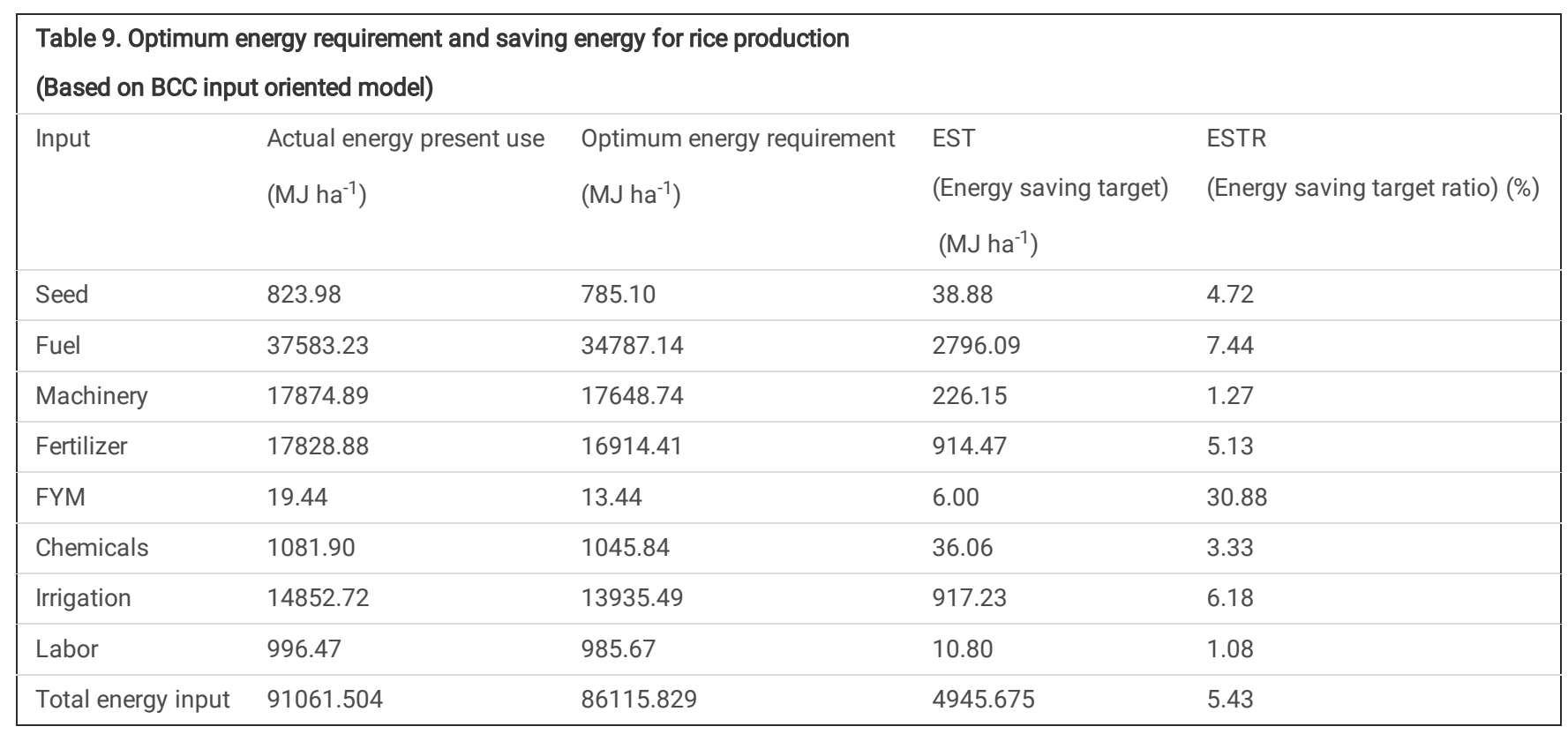

\begin{tabular}{|lllll|}
\hline \multicolumn{4}{|l}{ Table 10. Improvement of energy indices for rice production in Mazandaran provice, Iran. } \\
\hline Item & Unit & Present quantity & Optimum quantity & Difference (\%) \\
\hline Energy use efficiency & - & 1.109 & 1.172 & 5.38 \\
\hline Energy productivity & $\mathrm{Kg} \mathrm{MJ}^{-1}$ & 0.059 & 0.061 & 3.28 \\
\hline Specific energy & $\mathrm{MJ} \mathrm{kg}^{-1}$ & 17.24 & 16.39 & -5.19 \\
\hline Net energy & $\mathrm{MJ} \mathrm{ha}^{-1}$ & 9906.45 & 14852.13 & 33.30 \\
\hline Direct energy & $\mathrm{MJ} \mathrm{ha}^{-1}$ & $53451.86(58.70 \%)$ & $49721.74(57.74 \%)$ & -7.50 \\
\hline Indirect energy & $\mathrm{MJ} \mathrm{ha}^{-1}$ & $37609.64(41.30 \%)$ & $36394.09(42.26 \%)$ & -3.34 \\
\hline Renewable energy & $\mathrm{MJ} \mathrm{ha}^{-1}$ & $16692.61(18.33 \%)$ & $15719.70(18.25 \%)$ & -6.19 \\
\hline Non-renwable energy & $\mathrm{MJ} \mathrm{ha}^{-1}$ & $74368.90(81.67 \%)$ & $70396.13(81.75 \%)$ & -5.64 \\
\hline Total energy input & $\mathrm{MJ} \mathrm{ha}^{-1}$ & 91061.50 & 86115.82 & -5.74 \\
\hline
\end{tabular}




\begin{tabular}{|c|c|c|c|c|c|c|c|c|c|c|c|c|}
\hline \multirow[b]{2}{*}{$\begin{array}{l}\text { Inefficient } \\
\text { farmers } \\
\text { No. }\end{array}$} & \multirow[b]{2}{*}{ PTE } & \multicolumn{8}{|c|}{ Actual energy $\left(\mathrm{MJ} \mathrm{ha}^{-1}\right)$} & \multicolumn{3}{|c|}{ Optimum energy requirement } \\
\hline & & Seed & Fuel & Machinery & Fertilizer & FYM & Chemicals & Irrigation & Labor & Seed & Fuel & Machi \\
\hline 9 & 0.991 & 994.60 & 24031.00 & 7812.48 & 16906.85 & 31.20 & 557.72 & 10286.01 & 1468.19 & 755.19 & 23815.39 & $7742 . \AA$ \\
\hline 14 & 0.995 & 1021.06 & 24760.28 & 9684.89 & 9669.13 & 31.20 & 766.14 & 10455.00 & 1453.20 & 722.14 & 24631.56 & 9634.5 \\
\hline 15 & 0.987 & 867.59 & 25461.68 & 15883.23 & 7546.24 & 93.61 & 1097.11 & 10292.06 & 1452.04 & 836.41 & 24627.06 & 15230 \\
\hline 28 & 0.922 & 907.05 & 26401.73 & 14139.94 & 27387.98 & 62.40 & 992.89 & 11343.84 & 1270.39 & 836.38 & 24344.75 & 13038 \\
\hline 38 & 0.998 & 751.32 & 29354.76 & 16076.92 & 14192.87 & 14.45 & 813.73 & 12184.12 & 1074.90 & 749.48 & 29296.02 & 16044 \\
\hline 41 & 0.980 & 805.35 & 30638.82 & 16593.45 & 20233.45 & 156.01 & 925.34 & 12656.78 & 1026.46 & 788.95 & 30014.89 & 16255 \\
\hline 49 & 0.995 & 830.34 & 34711.84 & 18070.77 & 10714.03 & 62.40 & 1115.44 & 14704.97 & 956.11 & 823.65 & 34524.46 & 17973 \\
\hline 53 & 0.998 & 834.96 & 35493.95 & 18080.98 & 18755.67 & 187.21 & 766.14 & 16007.41 & 927.86 & 795.56 & 35410.10 & 18038 \\
\hline 67 & 0.952 & 807.32 & 44444.89 & 20410.10 & 20267.65 & 31.20 & 1099.99 & 16805.68 & 889.22 & 768.68 & 42317.36 & 19433 \\
\hline 70 & 0.988 & 833.49 & 46307.17 & 20607.61 & 21044.20 & 62.40 & 821.13 & 17068.27 & 885.18 & 823.77 & 45766.96 & 20367 \\
\hline 75 & 0.948 & 754.54 & 49513.56 & 21952.43 & 20062.42 & 31.20 & 1323.86 & 17645.97 & 814.25 & 715.46 & 46850.69 & 20815 \\
\hline 76 & 0.951 & 875.50 & 50315.15 & 22282.95 & 22719.62 & 62.40 & 925.34 & 17856.04 & 771.00 & 777.98 & 47840.13 & 21186 \\
\hline 84 & 0.952 & 781.86 & 52645.79 & 24535.06 & 27566.03 & 62.40 & 1237.98 & 29106.39 & 583.01 & 744.29 & 50116.08 & 23356 \\
\hline 94 & 0.975 & 817.97 & 56364.11 & 27117.70 & 25111.13 & 31.20 & 1996.59 & 23400.76 & 359.26 & 763.69 & 54968.47 & 26446 \\
\hline 96 & 0.976 & 980.38 & 63386.17 & 27782.02 & 26136.14 & 78.00 & 1237.98 & 21294.27 & 347.15 & 749.03 & 59849.11 & 27121 \\
\hline Ave. & 0.974 & 857.56 & 39588.73 & 18735.37 & 19220.90 & 66.49 & 1045.16 & 16073.84 & 951.88 & 776.71 & 38291.53 & 18178 \\
\hline
\end{tabular}




\begin{tabular}{|c|c|c|c|c|c|c|c|c|c|}
\hline Inefficient farmers No. & PTE & Seed & Fuel & Machinery & Fertilizer & FYM & Chemicals & Irrigation & Labor \\
\hline 9 & 0.991 & 230.49 & 0.00 & 0.00 & 0.00 & 0.00 & 16.72 & 0.00 & 0.00 \\
\hline 14 & 0.995 & 293.61 & 0.00 & 0.00 & 0.00 & 0.00 & 9.45 & 0.00 & 0.00 \\
\hline 15 & 0.987 & 19.48 & 491.03 & 438.40 & 0.00 & 92.19 & 269.27 & 0.00 & 0.00 \\
\hline 18 & 1.000 & 184.48 & 5348.14 & 3273.47 & 0.00 & 0.00 & 173.04 & 0.00 & 0.00 \\
\hline 19 & 1.000 & 114.50 & 1463.70 & 1494.81 & 0.00 & 0.00 & 312.29 & 0.00 & 0.00 \\
\hline 20 & 1.000 & 157.27 & 3690.79 & 2400.46 & 0.00 & 0.00 & 11.41 & 0.00 & 0.00 \\
\hline 22 & 1.000 & 197.52 & 5805.41 & 25.21 & 0.00 & 0.00 & 0.00 & 0.00 & 0.00 \\
\hline 25 & 1.000 & 20.71 & 0.00 & 141.73 & 226.50 & 0.00 & 0.00 & 85.74 & 0.00 \\
\hline 26 & 1.000 & 189.34 & 3877.61 & 472.37 & 0.00 & 0.00 & 0.00 & 101.32 & 0.00 \\
\hline 27 & 1.000 & 184.12 & 15126.06 & 519.71 & 9962.82 & 0.00 & 634.82 & 0.00 & 0.00 \\
\hline 28 & 0.922 & 0.00 & 0.00 & 0.00 & 4899.39 & 39.70 & 0.00 & 0.00 & 0.00 \\
\hline 29 & 1.000 & 175.74 & 3858.82 & 74.92 & 0.00 & 0.00 & 0.00 & 0.00 & 0.00 \\
\hline 30 & 1.000 & 197.27 & 4674.04 & 1046.82 & 0.00 & 0.00 & 0.00 & 139.47 & 0.00 \\
\hline 31 & 1.000 & 2.45 & 3413.31 & 226.15 & 0.00 & 0.00 & 0.00 & 0.00 & 0.00 \\
\hline 32 & 1.000 & 2.39 & 2825.10 & 0.00 & 0.00 & 0.00 & 106.94 & 0.00 & 0.00 \\
\hline 35 & 1.000 & 4.04 & 2067.99 & 0.00 & 0.00 & 0.00 & 138.68 & 0.00 & 0.00 \\
\hline 37 & 1.000 & 0.00 & 1015.37 & 0.00 & 0.00 & 0.00 & 623.10 & 0.00 & 0.00 \\
\hline 38 & 0.998 & 0.34 & 0.00 & 0.00 & 0.00 & 0.00 & 0.00 & 0.00 & 0.00 \\
\hline 41 & 0.980 & 0.00 & 0.00 & 0.00 & 0.00 & 113.96 & 0.00 & 0.00 & 0.00 \\
\hline 42 & 1.000 & 34.69 & 7470.31 & 0.00 & 1909.93 & 0.00 & 0.00 & 0.00 & 0.00 \\
\hline 44 & 1.000 & 14.35 & 2433.34 & 0.00 & 4575.29 & 0.00 & 0.00 & 256.04 & 0.00 \\
\hline 49 & 0.995 & 2.21 & 0.00 & 0.00 & 0.00 & 32.64 & 92.31 & 0.00 & 0.00 \\
\hline 50 & 1.000 & 10.13 & 7723.85 & 0.00 & 0.00 & 0.00 & 75.21 & 419.08 & 0.00 \\
\hline 52 & 1.000 & 9.02 & 7684.03 & 0.00 & 0.00 & 0.00 & 32.41 & 2959.10 & 0.00 \\
\hline 53 & 0.998 & 37.42 & 0.00 & 0.00 & 0.00 & 111.59 & 0.00 & 1692.52 & 0.00 \\
\hline 55 & 1.000 & 30.81 & 0.00 & 0.00 & 0.00 & 0.00 & 0.00 & 1223.00 & 0.00 \\
\hline 56 & 1.000 & 46.71 & 4394.59 & 0.00 & 0.00 & 0.00 & 438.74 & 1889.62 & 0.00 \\
\hline 57 & 1.000 & 49.64 & 4535.34 & 0.00 & 0.00 & 0.00 & 117.53 & 1292.63 & 0.00 \\
\hline 58 & 1.000 & 19.22 & 2612.56 & 0.00 & 0.00 & 0.00 & 0.00 & 2600.94 & 0.00 \\
\hline 59 & 1.000 & 10.54 & 2013.53 & 0.00 & 0.00 & 0.00 & 0.00 & 3396.35 & 0.00 \\
\hline 60 & 1.000 & 0.00 & 0.00 & 0.00 & 0.00 & 0.00 & 0.00 & 2031.80 & 0.00 \\
\hline 61 & 1.000 & 45.71 & 6803.37 & 0.00 & 0.00 & 0.00 & 0.00 & 1929.85 & 6.30 \\
\hline 62 & 1.000 & 66.08 & 6952.40 & 0.00 & 0.00 & 0.00 & 0.00 & 2437.29 & 4.12 \\
\hline 63 & 1.000 & 82.80 & 9419.60 & 0.00 & 0.00 & 0.00 & 0.00 & 3001.42 & 16.23 \\
\hline 64 & 1.000 & 54.85 & 11811.34 & 0.00 & 0.00 & 0.00 & 0.00 & 2437.55 & 66.14 \\
\hline 66 & 1.000 & 33.58 & 4350.41 & 347.52 & 7528.36 & 0.00 & 0.00 & 1182.47 & 80.50 \\
\hline 67 & 0.952 & 0.00 & 0.00 & 0.00 & 0.00 & 0.00 & 0.00 & 0.00 & 0.00 \\
\hline 68 & 1.000 & 190.45 & 14266.39 & 0.00 & 0.00 & 0.00 & 0.00 & 3339.32 & 11.78 \\
\hline 70 & 0.988 & 0.00 & 0.00 & 0.00 & 0.00 & 23.25 & 0.00 & 0.00 & 98.85 \\
\hline 73 & 1.000 & 0.00 & 4109.02 & 0.00 & 2779.19 & 0.00 & 0.00 & 976.10 & 63.88 \\
\hline 74 & 1.000 & 0.00 & 1858.33 & 0.00 & 1340.47 & 0.00 & 0.00 & 564.32 & 0.00 \\
\hline 75 & 0.948 & 0.00 & 98.41 & 0.00 & 0.00 & 15.09 & 0.00 & 1569.20 & 0.00 \\
\hline
\end{tabular}




\begin{tabular}{|llllllllll|}
76 & 0.951 & 54.45 & 0.00 & 0.00 & 0.00 & 11.45 & 0.00 & 0.00 & 73.27 \\
\hline 77 & 1.000 & 0.00 & 21322.09 & 471.97 & 280.68 & 0.00 & 0.00 & 3367.61 & 66.39 \\
\hline 78 & 1.000 & 0.00 & 12609.29 & 169.28 & 0.00 & 0.00 & 0.00 & 1947.45 & 50.95 \\
\hline 79 & 1.000 & 0.00 & 13176.94 & 804.74 & 1136.47 & 0.00 & 0.00 & 1134.24 & 67.67 \\
\hline 80 & 1.000 & 0.00 & 19659.39 & 807.15 & 1199.93 & 0.00 & 0.00 & 4997.01 & 35.72 \\
\hline 81 & 1.000 & 0.00 & 13879.00 & 449.03 & 2762.11 & 0.00 & 0.00 & 903.64 & 59.46 \\
\hline 82 & 1.000 & 0.14 & 5780.92 & 341.73 & 7481.59 & 0.00 & 0.00 & 1078.06 & 28.10 \\
\hline 83 & 1.000 & 3.56 & 13217.70 & 327.02 & 1078.94 & 0.00 & 0.00 & 1733.50 & 0.00 \\
\hline 84 & 0.952 & 0.00 & 0.00 & 0.00 & 1557.65 & 51.21 & 0.00 & 11201.15 & 0.00 \\
\hline 85 & 1.000 & 0.00 & 5145.89 & 0.00 & 31863.18 & 0.00 & 0.00 & 0.00 & 0.00 \\
\hline 93 & 1.000 & 179.68 & 2128.19 & 81.69 & 1943.89 & 0.00 & 0.00 & 3070.13 & 0.00 \\
\hline 94 & 0.975 & 34.03 & 0.00 & 0.00 & 0.00 & 12.32 & 109.99 & 9947.60 & 3.22 \\
\hline 95 & 1.000 & 363.05 & 1626.82 & 792.15 & 0.00 & 0.00 & 0.00 & 8691.47 & 0.00 \\
\hline 96 & 0.976 & 208.04 & 2029.66 & 0.00 & 0.00 & 73.85 & 0.00 & 1276.72 & 0.00 \\
\hline
\end{tabular}

\begin{tabular}{|lll|}
\hline \multicolumn{3}{|l|}{ Table 13. Economic analysis of rice production in Mazandaran province, Iran } \\
\hline Cost and return components & Unit & Value \\
\hline Rice grain yield & $\mathrm{kg} \mathrm{ha}^{-1}$ & 2167 \\
\hline Byproduct yield & $\mathrm{kg} \mathrm{ha}^{-1}$ & 978 \\
\hline Rice price & $\$ \mathrm{~kg}^{-1}$ & 1.529 \\
\hline Byproduct price & $\$ \mathrm{~kg}^{-1}$ & 0.082 \\
\hline Rice value & $\$ \mathrm{ha}^{-1}$ & 3314.235 \\
\hline Byproduct value & $\$ \mathrm{ha}^{-1}$ & 80.541 \\
\hline Total gross value & $\$ \mathrm{ha}^{-1}$ & 3394.776 \\
\hline Fix cost of production & $\$ \mathrm{ha}^{-1}$ & 793.823 \\
\hline Variable cost of production & $\$ \mathrm{ha}^{-1}$ & 1323.039 \\
\hline Total cost of production & $\$ \mathrm{ha}^{-1}$ & 2116.862 \\
\hline Gross return & $\$ \mathrm{ha}^{-1}$ & 2071.738 \\
\hline Net return & $\$ \mathrm{ha}^{-1}$ & 1277.914 \\
\hline Benefit to cost ratio & - & 1.604 \\
\hline Economic productivity & $\mathrm{kg} \mathrm{S}^{-1}$ & 1.024 \\
\hline Energy intensiveness & $\mathrm{MJ} \mathrm{\$}^{-1}$ & 43.017 \\
\hline Energy intensiveness value & $\mathrm{MJ} \mathrm{S}^{-1}$ & 26.824 \\
\hline Energy intensity cost & - & 0.481 \\
\hline Energy ratio cost & 0.492 \\
\hline
\end{tabular}




\begin{tabular}{|c|c|c|c|}
\hline Input & $\begin{array}{l}\text { Present GHG emission } \\
\left(\mathrm{kg} \mathrm{CO}_{2} \text { eq ha-1) }\right.\end{array}$ & $\begin{array}{l}\text { Target GHG emission } \\
\left(\mathrm{kg} \mathrm{CO}_{2} \text { eq ha-1) }\right.\end{array}$ & $\begin{array}{l}\text { GHG reduction } \\
\left(\mathrm{kg} \mathrm{CO}_{2} \text { eq ha-1) }\right.\end{array}$ \\
\hline Machinery & 1269.117 & 1242.051 & 27.066 \\
\hline Diesel & 1842.119 & 1811.108 & 31.011 \\
\hline \multicolumn{4}{|l|}{ Chemical fertilizer } \\
\hline Nitrogen & 301.542 & 295.720 & 5.823 \\
\hline Phosphate & 19.204 & 18.877 & 0.327 \\
\hline Potassium & 16.535 & 14.869 & 1.666 \\
\hline \multicolumn{4}{|l|}{ Chemicals } \\
\hline Insecticide & 34.593 & 31.287 & 3.306 \\
\hline Herbicide & 11.228 & 11.085 & 0.143 \\
\hline Fungicide & 0.042 & 0.031 & 0.011 \\
\hline Electricity & 756.953 & 721.187 & 35.766 \\
\hline Total GHG emission & 4251.333 & 4146.215 & 105.118 \\
\hline
\end{tabular}

\section{Figures}

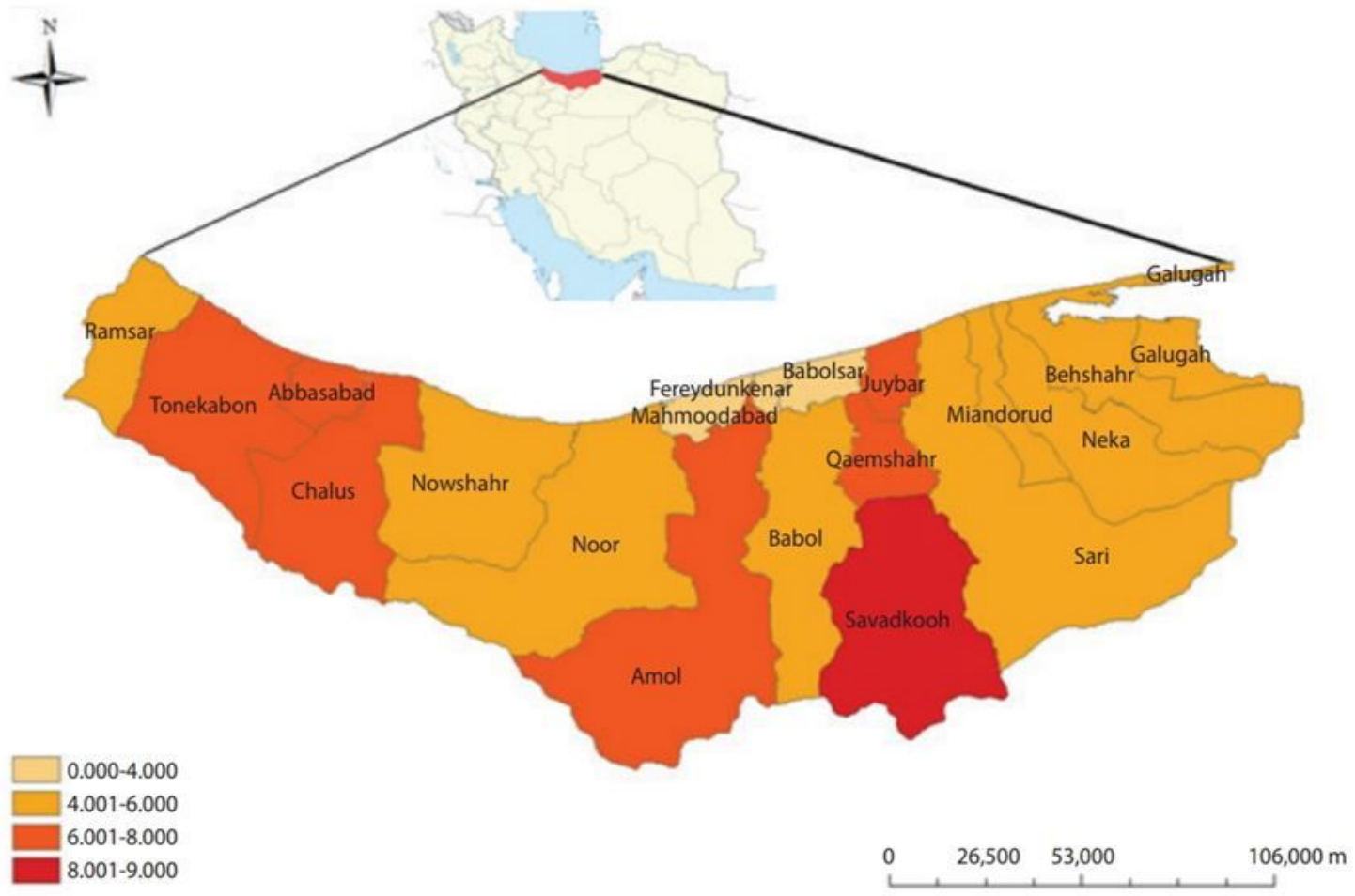

Figure 1

Geographical location of the studied rigion (Mazandaran province in north of Iran). Note: The designations employed and the presentation of the material on this map do not imply the expression of any opinion whatsoever on the part of Research Square concerning the legal status of any country, territory, city or area or of its authorities, or concerning the delimitation of its frontiers or boundaries. This map has been provided by the authors. 


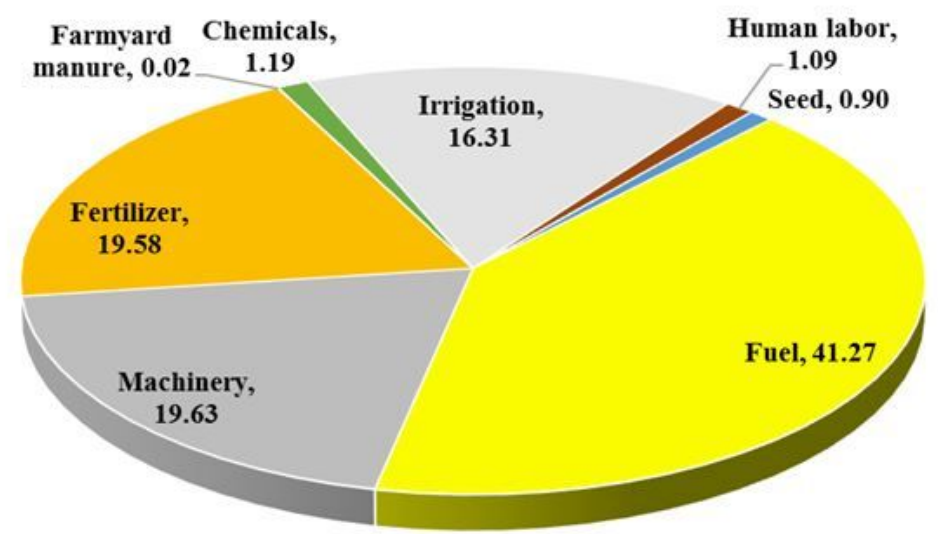

Figure 2

The share of total mean energy inputs for rice production in Mazandaran province, Iran

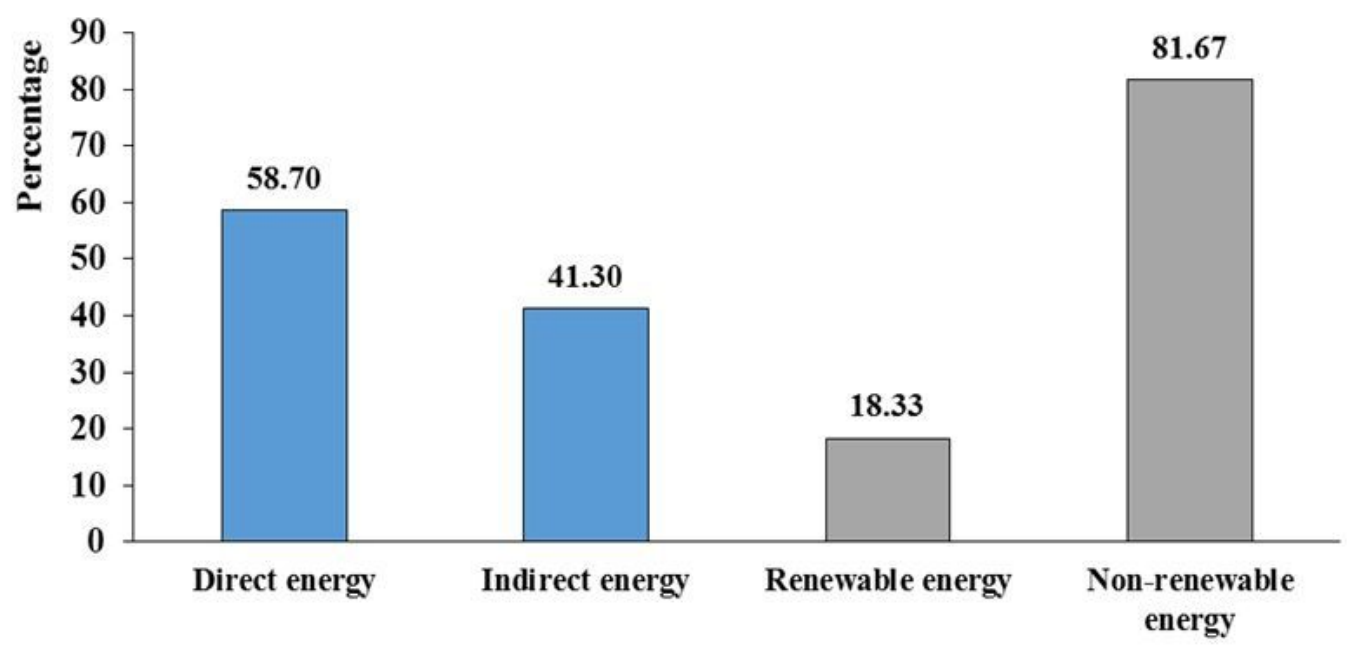

Figure 3

The share of total energy input in the form of direct, indirect, renewable and non-renewable source of rice production in Mazandran province, Iran.

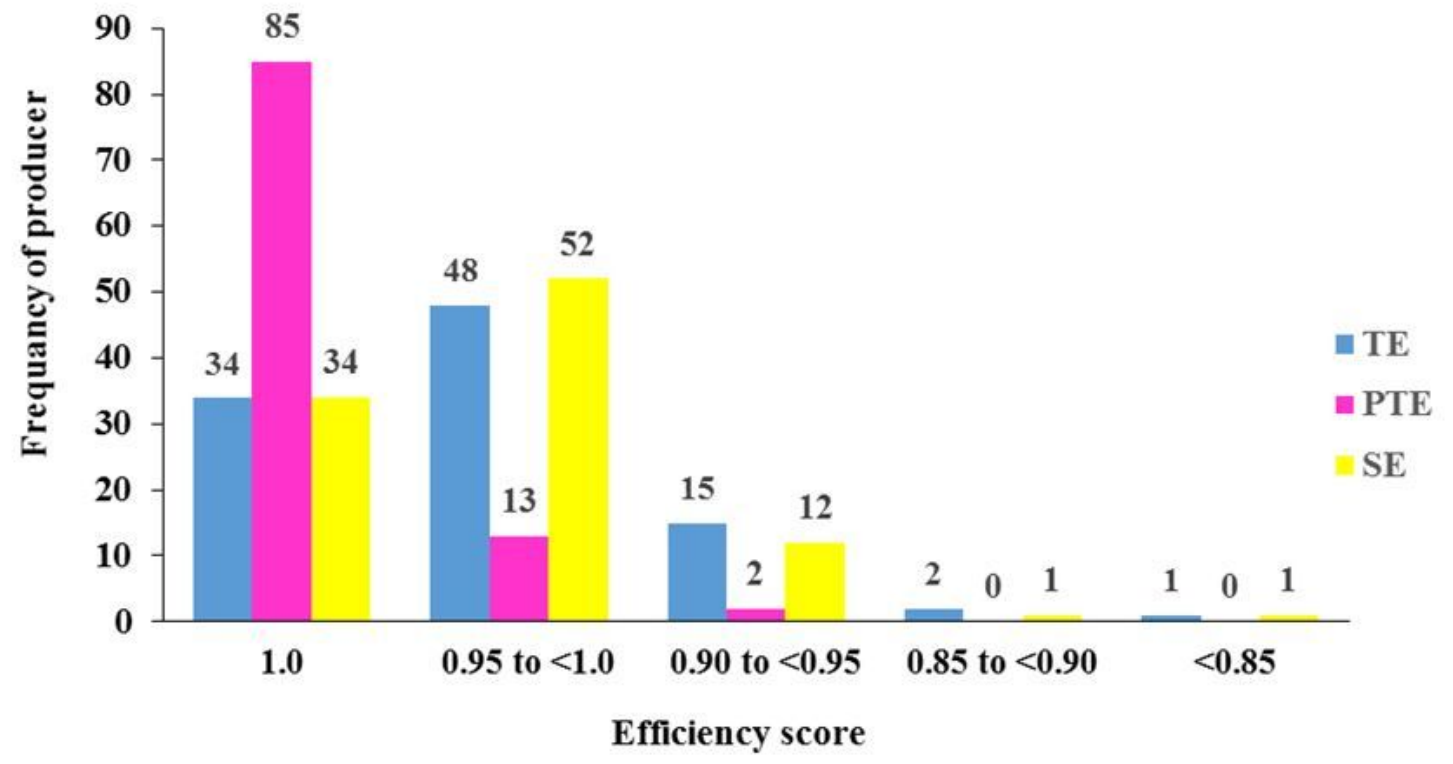


Figure 4

Efficiency score distribution of rice producer in Mazandaran province, Iran

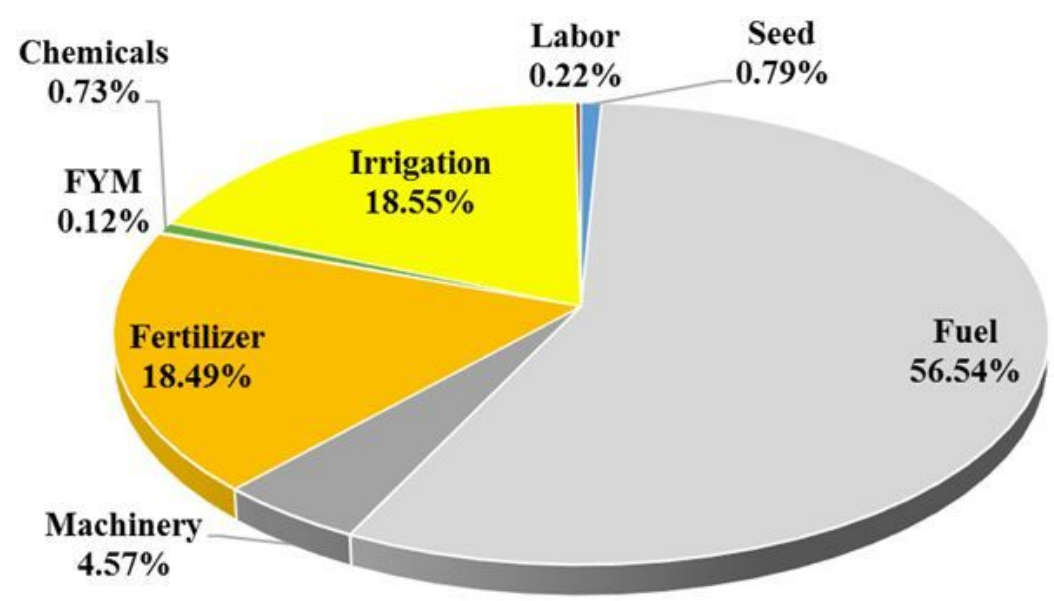

Figure 5

Contribution to the total saving energy of rice producer in Mazandaran province, Iran

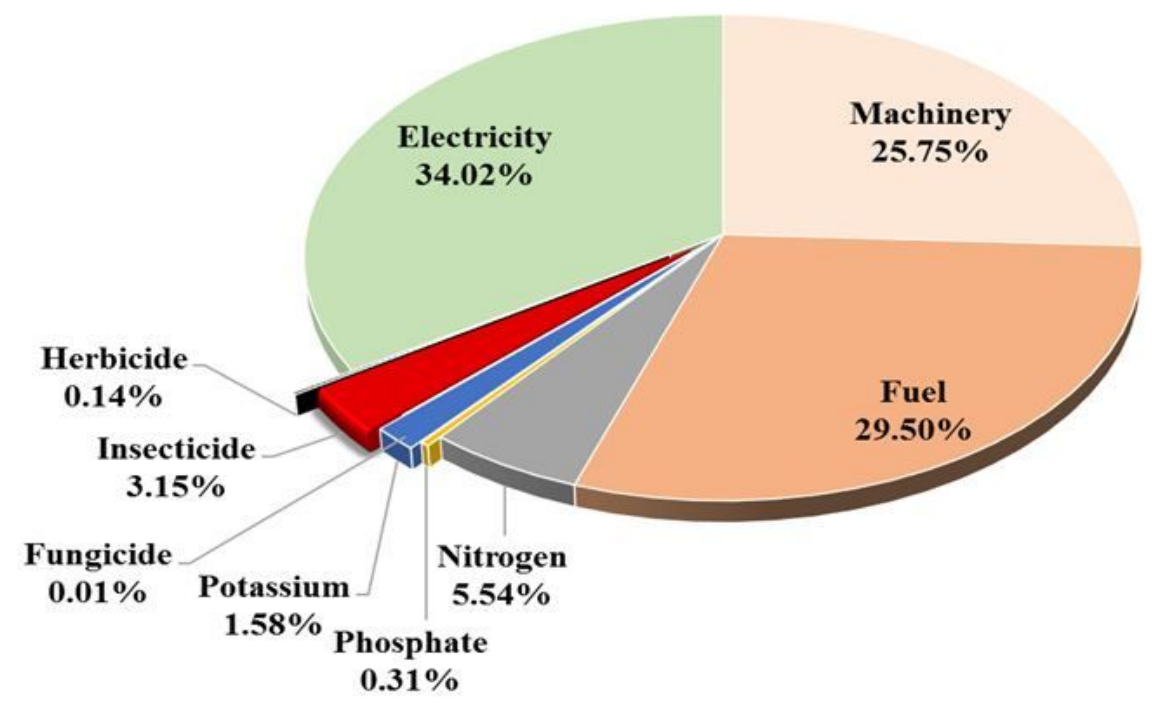

Figure 6

The share of each input emission reduction of for GHG rice production.

\section{Supplementary Files}

This is a list of supplementary files associated with this preprint. Click to download.

- Highlights.docx

- EQUATIONS.docx 